\title{
Shifting Identities in Buddhist Sculpture: Who's Who in the Murō-ji Kondō ${ }^{\star}$
}

\author{
SHERRY FOWLER \\ UNIVERSITY OF KANSAS
}

As one of the rare structures preserving both architecture and sculpture of the Heian period (794-I I85), the Murōji kondo serves as an outstanding example of an environment from which to gain a better understanding of religious establishments of this period in Japan. Although the temple of Murō-ji is located in the remote countryside on Mt. Murō in the Uda district of Nara Prefecture (Fig. 1), the icons of its kondō ("golden hall") are major monuments of Japanese Buddhist sculpture. As individual works, these pieces have been published frequently, and are included in most textbooks on Japanese art history, but with little thought to how they may have functioned as a group. Five large wooden images with painted wooden mandorlas, dating from the ninth to the tenth centuries, are at present lined up across the kondō altar. Their present configuration, however, was not their original one, nor have the identities of the individual images remained unchanged over time.

The five sculptures at present on the altar (from proper right to left) in the Murō-ji kondō are designated as

Jūichimen (Eleven-headed) Kannon Bosatsu (S: Ekādaśamukha Avalokiteśvara Bodhisattva), Monju Bosatsu (S: Mañjuśrī Bodhisattva), Shaka Nyorai (S: Śākyamuni Buddha), Yakushi Nyorai (S: Bhaișajyaguru Buddha), and Jizō Bosatsu (S: Kșitigarbha Bodhisattva) (Fig. 2). For the most part, Japanese Buddhist altars hold only three iconsa central Buddha image and two flanking bodhisattvas. Pentads, less common, are certainly not unknown, but almost invariably consist of a central Buddha, the two bodhisattvas who canonically or customarily form a triad with that Buddha, and, flanking these, two of Shaka's original disciples or two monks. The present anomalous assemblage of two Buddhas and three bodhisattavas (with no two of the latter normally paired in iconic arrangements) evokes speculation that this was not the original configuration of the kondo altar-that the images were at some point in their history "recycled." In the first section of this article I propose that the Murō-ji kondō altar originally held only three icons, and discuss their identities and the rationale of grouping them for worship.The latter section will be devot-

Fig. I. Mt. Murō, Uda district, Nara Prefecture. Photograph by author.

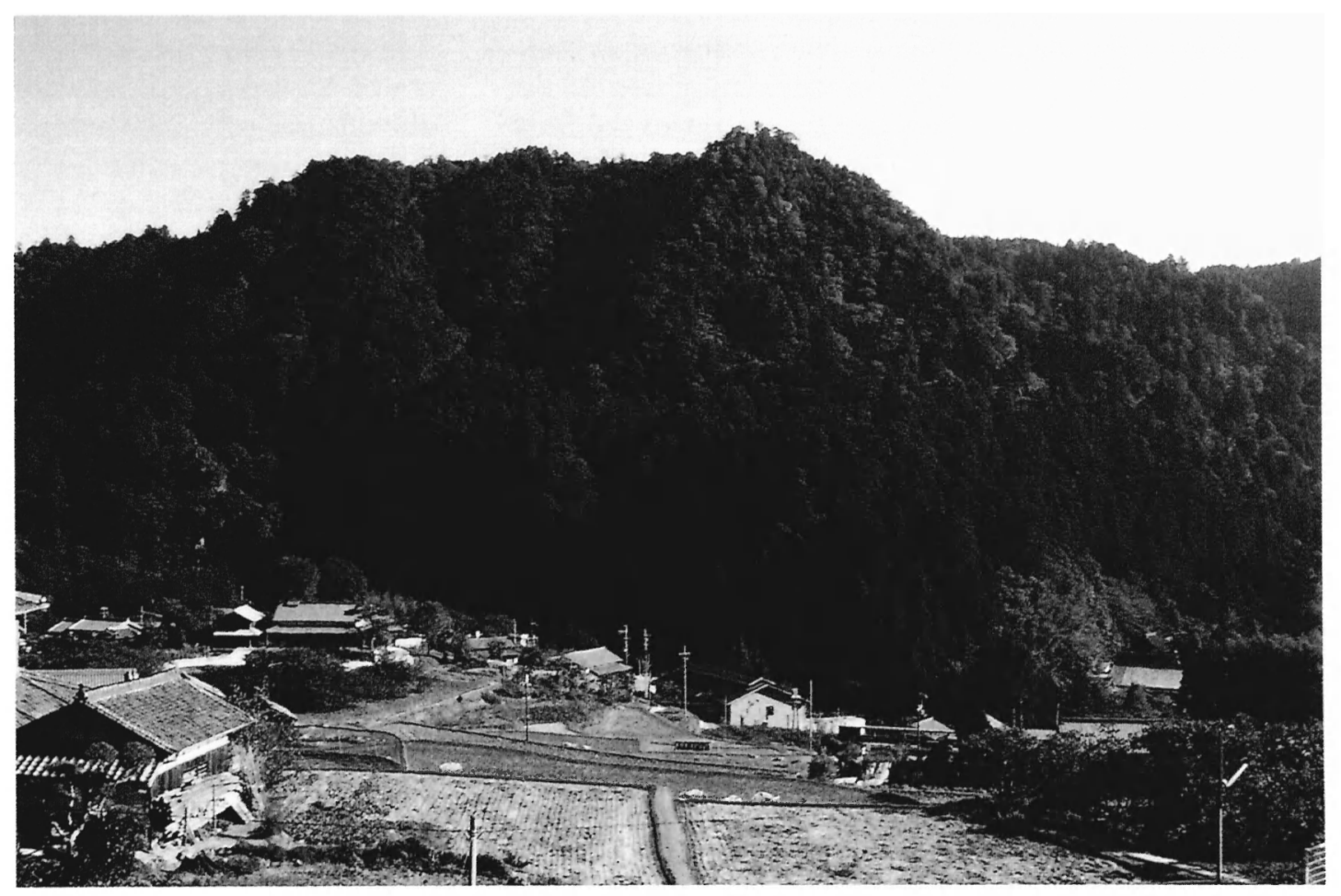




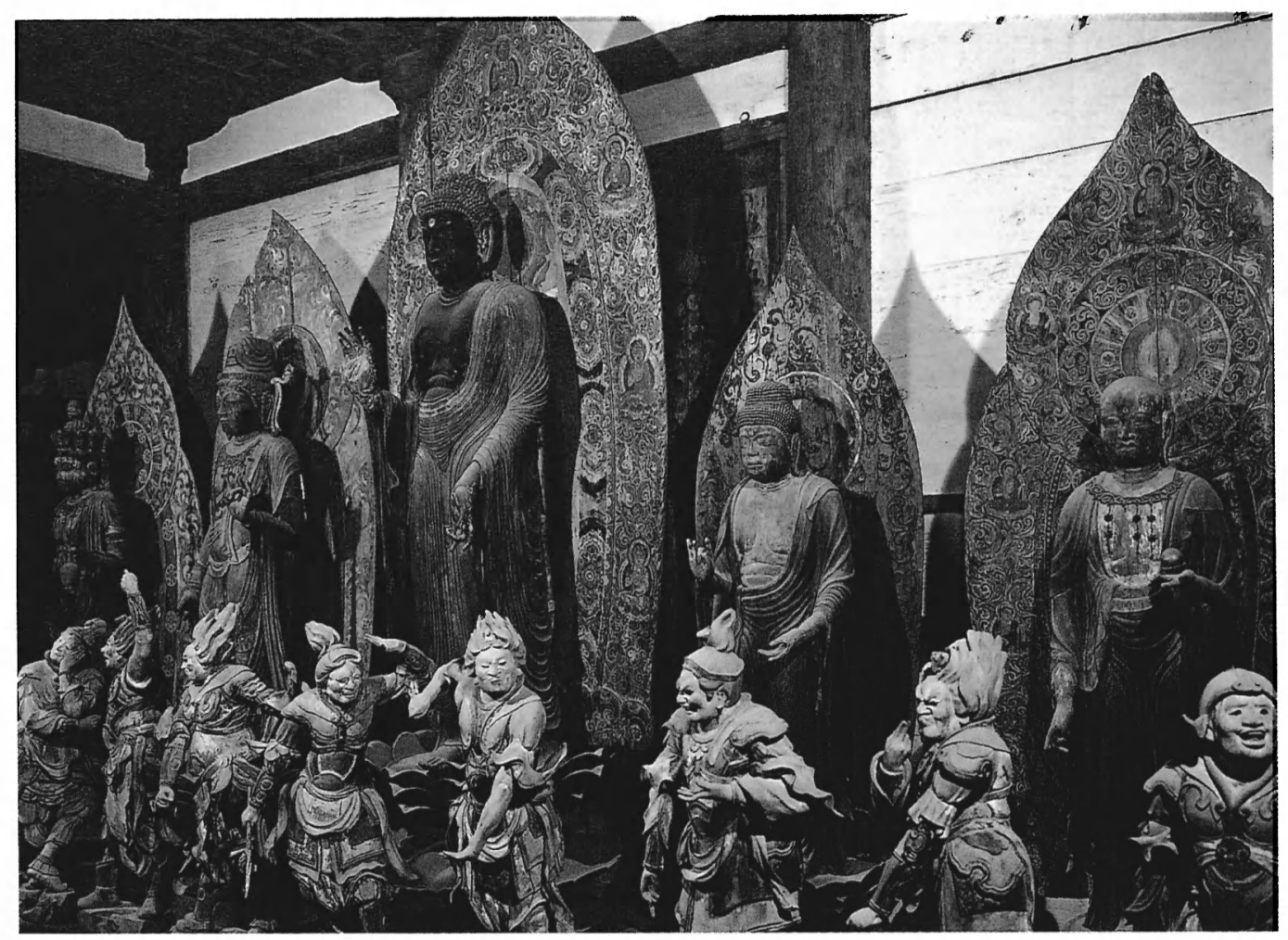

Fig. 2. Kondō interior. Murō-ji, Nara Prefecture. Photograph courtesy of Asukaen.

ed to an interpretation of the present five images on the altar, their identities and their arrangement, and to a consideration of how these images might have changed over time.

But first let us consider the building where the images are located (Fig. 3). The kondo, constructed originally in the mid to late ninth century, has undergone several transformations; nevertheless, it still maintains some of its original architectural character. ${ }^{\mathrm{I}}$ The original section of the building is five bays wide and four bays deep; to the front of this, in the late seventeenth century, a worship hall (raid $\dot{0}$ ) was added along with a skirting veranda enclosed by a railing. ${ }^{2}$ The addition extends out over a descending slope and is supported by wooden beams and pillars resting on two stone platforms. ${ }^{3}$ Inside the inner sanctuary (naijin) of the hall, the Buddhist icons stand upon an altar measuring three bays, placed in front of an interior wall of the same width.

In the center of the altar stands the Main Image (honzon) of the kondō, which in I90I was registered as a National Treasure under the name Shaka, although up to that time it had usually been identified as an image of Yakushi, the Healing Buddha (Fig. 4). ${ }^{4}$ For clarity, I shall refer to this sculpture as the Main Image throughout this article. Standing $234.8 \mathrm{~cm}$ in height and with full, thick features, the Main Image exudes an aura of power. It is superbly carved, in a style consistent with that of images from the late ninth to the early tenth century. Its right hand is raised, with palm forward, in the mudra known as semui' in, conferring reassurance or freedom from fear, a gesture frequently seen in
Japanese figures of Yakushi. In the left hand Japanese representations of Yakushi most commonly hold a medicine jar (yakko), but the Main Image at Murō-ji is empty-handed; instead, the left hand is held down, palm outward with second and third fingers folded up, in the yogan'in mudrā of compassionate giving. The Tendai manual Asabasho (Notes on the Buddha [a], Lotus [sa], and Diamond [ba] Sections [of the Womb World]), compiled Ninji 3-Kōan 4 (I242-I28I) by Shōchō (I205-I28I), notes that some images of Yakushi Nyorai, including the one at Murō-ji, do not hold a medicine jar. ${ }^{5}$ Various temple records and two fourteenth-century maps also afford evidence that the building was referred to as a Yakushido ("Yakushi hall"). ${ }^{6}$ Scholars agree that the present wooden mandorla is original to the image and that the painted design of seven seated Buddha images symmetrically arranged around the mandorla signifies the concept known in Esoteric Buddhism as Shichibutsu Yakushi (the seven transformed bodies of Bhaișajyaguru). All the images on the Murō-ji altar have wooden mandorlas, but the Main Image is the only one whose mandorla appears to be original to the image. Moreover, in front of the five large sculptures on the kondō altar stands a set of smaller images of the Jünishinshō ("Twelve Guardian Generals"), standard attendants of Yakushi, dating from the late thirteenth century. All these indications support a reasonable assumption that this sculpture was originally enshrined in the hall as an image ofYakushi.

Originally, I believe the altar of the Murō-ji kondō held a triad consisting of Yakushi, Kannon, and Jizō, a hypothe- 
Fig. 3. Kondō exterior. Murō-ji, Nara Prefecture. $9^{\text {th }}$ c. Photograph by author.

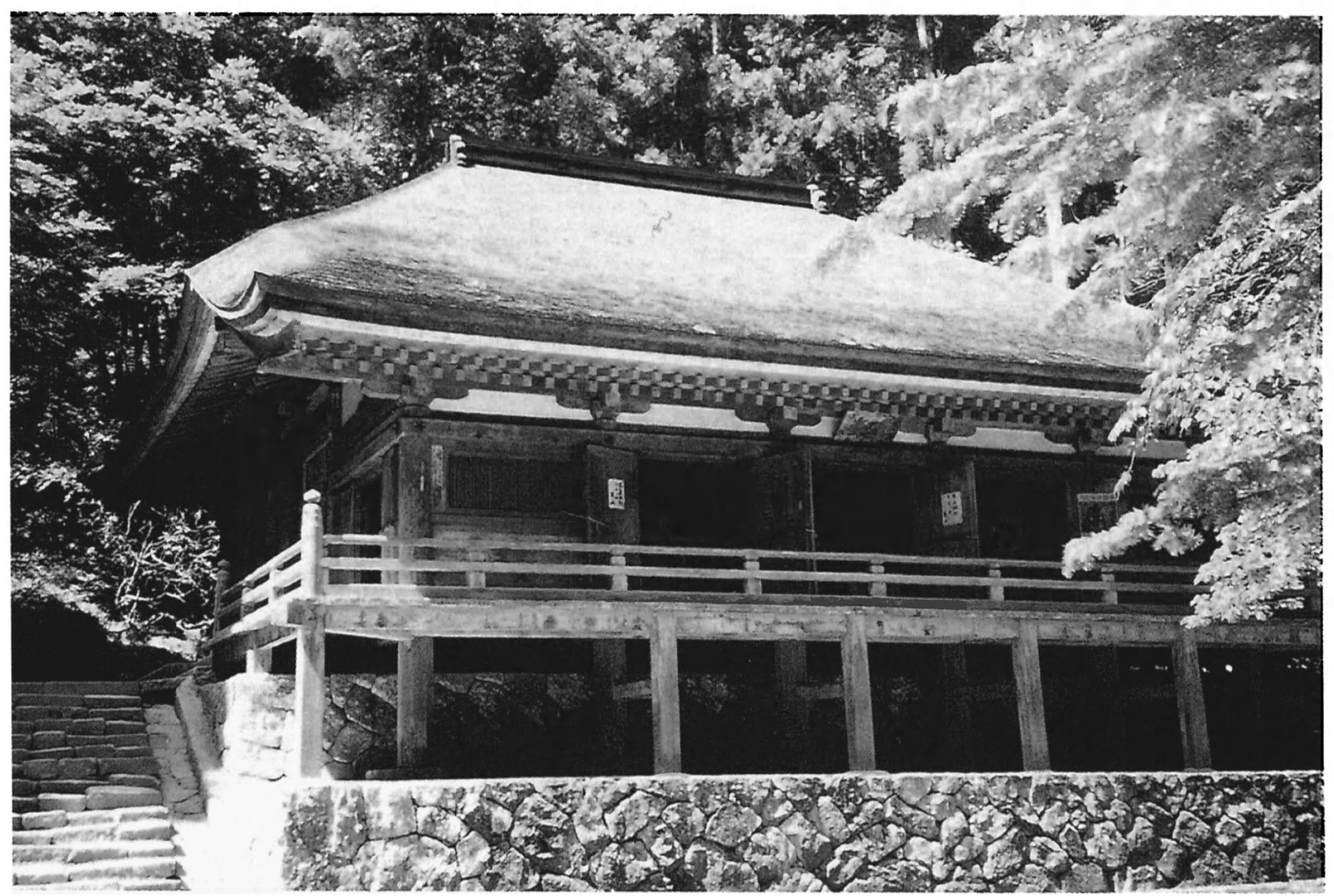

sis I will support with related material and documentary evidence from China, Korea, and Japan in addition to clues stemming from the locus of Murō-ji. Jizō is not often grouped with Yakushi, but a striking similarity in style and color between the Main Image and a sculpture found in nearby Sanbonmatsu village (Nakamura ward, Uda district, Nara Prefecture) offers compelling evidence for the proposition that the two statues were made at the same time, late ninth to early tenth century, as part of the same group (Fig. 5). The Sanbonmatsu Jizō now belongs to Anzan-ji, a new Buddhist temple with no doctrinal affiliation, run by the Nakamura ward. ${ }^{7}$ Prayers addressed to the Sanbonmatsu Jizō for easy childbirth are thought to be especially efficacious. This Jizo image bears an inscription stating that it was repaired in the Sanbonmatsu area in Jōkyō 5 (I 688) ${ }^{8}$

There are no known documents regarding the transfer or the installation of this image, but there is a legend. It is said that during a heavy rainstorm the image floated down the Uda River and washed up on the bank in Sanbonmatsu, and when the people of the village tried to carry the sculpture away, it would not budge. They finally realized that the Jizō wanted to remain where it was, so they made a hall at that site (the Shindo) where the image could be worshipped. ${ }^{9}$ The legend does not date this event, but it is an interesting fact that the Uda River passes in front of Murō.ji and flows on north past Sanbonmatsu.

Reinforcing their stylistic similarity, the difference in height between the kondo Main Image and the Sanbonmatsu Jizō $(234.8 \mathrm{~cm}$ for the former and $177.5 \mathrm{~cm}$ for the latter) further supports that suggestion that the Jizō was an attendant figure to the Main Image. The image of Jizō currently on the Murō-ji kondō altar is considerably smaller $(160.0 \mathrm{~cm})$ and of less distinguished workmanship than the Sanbonmatsu Jizō, although it also dates from about the tenth century (Fig. 6). Its magnificent Heian-period mandorla is clearly too large for it, since the central lotus flower, which should frame the image's head, instead lies well above it. For the Sanbonmatsu Jizō, on the other hand, this mandorla is properly proportioned, and its central lotus would perfectly frame the head. Moreover, in color and in painting style it strongly resembles the mandorla of the Main Image, although for iconographical reasons the painted images represent not a Buddha but Jizō. ${ }^{10}$ Reinforcing the theory that the Sanbonmatsu image originally belonged to a triad is the relaxed position of the right leg, with the weight shifted onto the left, a position known as yikyaku. Attendant images in Heian-period triads often hold the leg closest to the central image in yukvaku, so that they lean slightly toward the center. ${ }^{\text {II }}$ The attendants in the Ninna-ji Amida (S: Amitābha) triad of circa Ninna 4 (888), the Daigo-ji Yakushi triad of Engi I 3 (9I3), and the Kachio-ji Amida triad of the late ninth to the early tenth century all exemplify this posture. Following this pattern, the Sanbonmatsu Jizō would have been positioned to the left of the Main Image.

If Yakushi and Jizō were two members of the original Murō-ji triad, then who might the third have been? In the record known as Yamato Meishoshi (Records of Famous Places in Yamato), dated to circa I70I, the section on Murō.ji states that its honzon was a Shaka, flanked by Kannon 


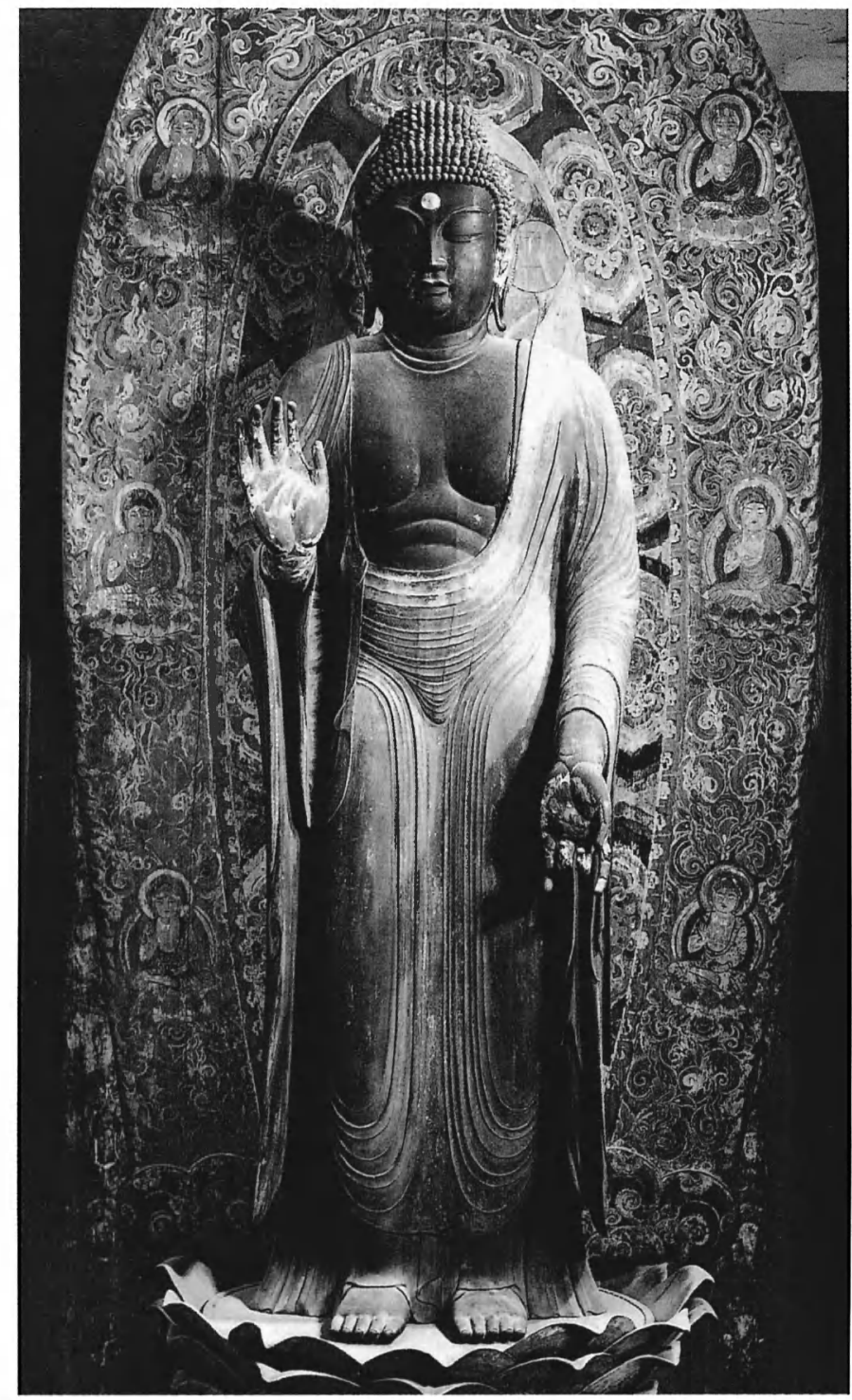

Fig. 4. Yakushi Nyorai (Main Image in kondō). Murō-ji, Nara Prefecture. $9^{\text {th }}$ c. Wood; h. $234.8 \mathrm{~cm}$. Photograph courtesy of Asukaen.

on the right and Jizō on the left. ${ }^{12}$ Assuming that this honzon and the present Main Image are one and the same, the identity of the Main Image must have shifted from Yakushi to Shaka by the time the document was written. ${ }^{13}$ Some temple and government sources of the eighteenth and nineteenth centuries, however, continued to identify the Main Image as Yakushi, ${ }^{14}$ demonstrating that the identity of the Main Image fluctuated during that period. The decision in Meiji 34 (I 90I) to register the Main Image as a National Treasure made it imperative to assign the image one single name.

Yamato Meishoshi provides strong evidence that my proposed triad, comprising the current Main Image, the Sanbonmatsu Jizo, and an image of Kannon, was in the

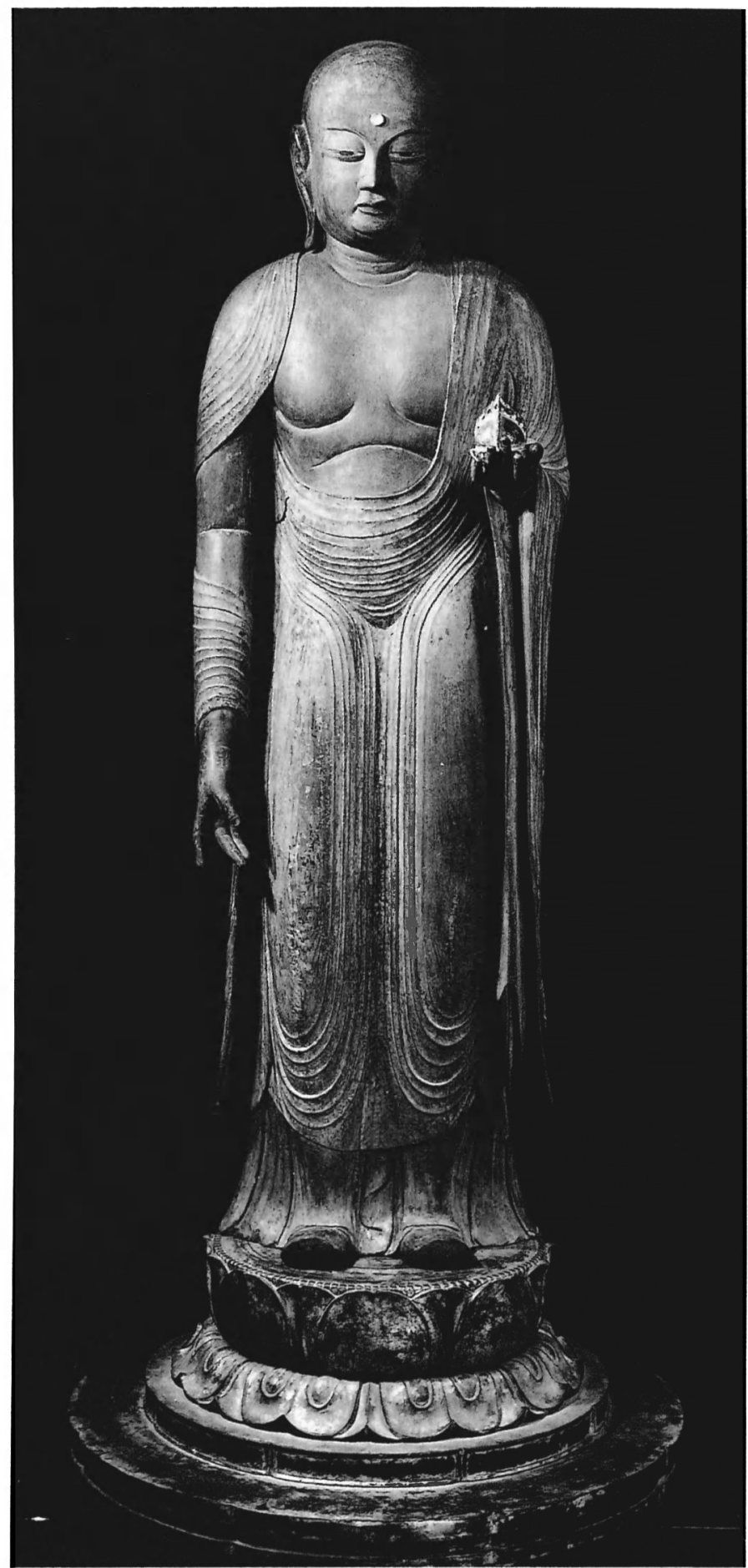

Fig. S. Jizō Bosatsu. Anzan-ji, Sanbonmatsu, Nara Prefecture. $9^{\text {th }} c$. Wood; h. $177.5 \mathrm{~cm}$. Photograph courtesy of Asukaen.

Murō-ji kondō about the time its information was compiled, the late seventeenth century. The record of repair inscribed on the Sanbonmatsu Jizō attests that it arrived at the Shindō by Jōkyō s (I688); Yamato Meishoshi's section 


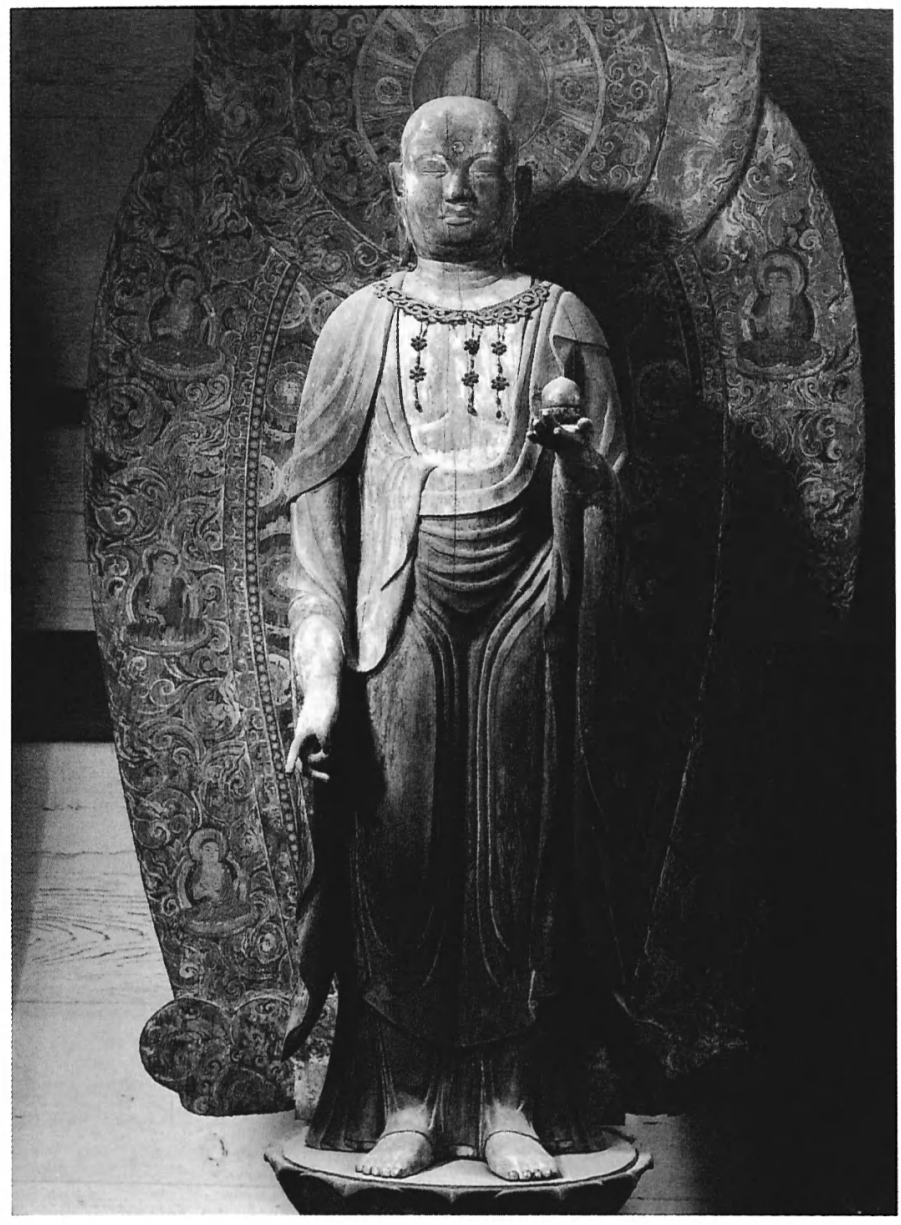

Fig. 6. Jizō Bosatsu. Murō-ji, Nara Prefecture. $10^{\text {th }}$ c. Wood; h. I60.0 $\mathrm{cm}$. Photograph courtesy of Asukaen.

on Yamabe (former name for the Sanbonmatsu area) is silent regarding the Shindō, which supports the inference that this document is describing the Murō-ji kondō at a time when it still included the Sanbonmatsu Jizō.

Among the many government records owned by the Nara Prefectural Library concerning Nara temples, Jiin Meisaichö-Detailed Records on Temples), dated Meiji 25 (I 892), includes some interesting evidence regarding an original triad at Murō-ji.After listing the five sculptures then in the kondō, the document adds a short descriptive statement including the following: "For a period of time they called the Main Image Yakushi and originally it was with Kannon and Jizō. In looking at these images now, the central image is Shaka and to its left is Yakushi." Is Although too recent to be strong evidence of the existence of an original YakushiKannon-Jizō triad, this record at least attests a prevailing belief that such a triad had once existed. It also asserts by omission that the present images of Yakushi and Monju are not original. Since the present grouping is iconographically unusual, and since temples generally claim long and dis-

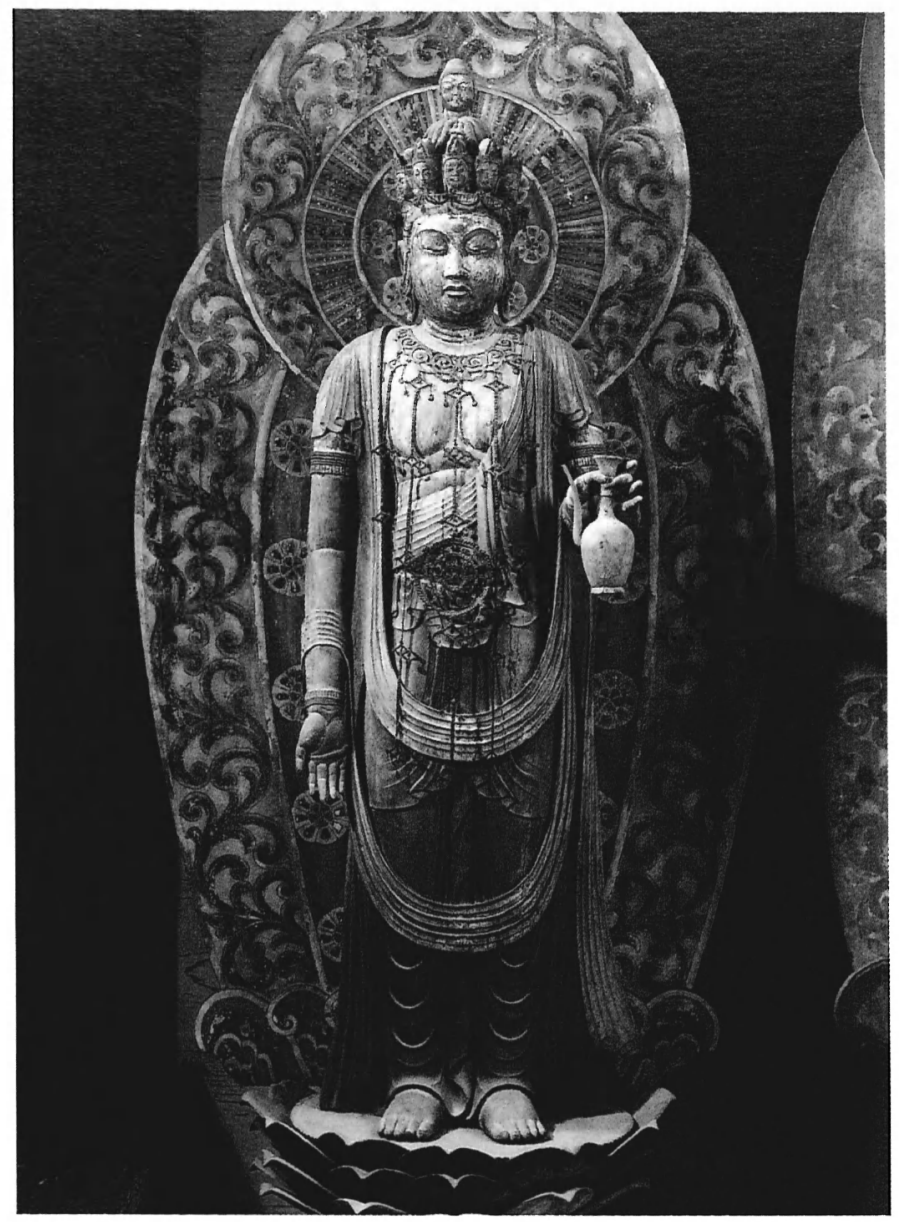

Fig. 7. Eleven-headed Kannon. Murō-ji, Nara Prefecture. $9^{\text {th }}$ c. Wood; h. $196.2 \mathrm{~cm}$. Photograph courtesy of Asukaen.

tinguished provenances to legitimize all their images, the statement should not be taken as mere coincidence.

The Eleven-headed Kannon presently in the kondō may very well be the image referred to in the above-mentioned records (Fig. 7). As the Eleven-headed Kannon (196.2 cm) is about twenty centimeters taller than the Sanbonmatsu Jizō $(177.5 \mathrm{~cm})$, the two images were obviously not made as a symmetrical pair; still, it is of an appropriate height to accompany the Main Image. Unfortunately, the mandorla of the Eleven-headed Kannon (unlike that of the Jizō) dates from the Meiji period (I868-I9I2), so that stylistic comparison with the mandorlas of the Main Image and the Jizō would be fruitless for my hypothesis. But the base upon which the sculpture stands is original, and it is very likely that a wooden mandorla was originally attached to it. ${ }^{16}$

The resemblance between the Main Image and the Sanbonmatsu Jizo is so striking that it is logical to expect the third member of the triad to show the same style. In many cases, however, the three images of a triad were not made by the same sculptor and do not match stylistically, 


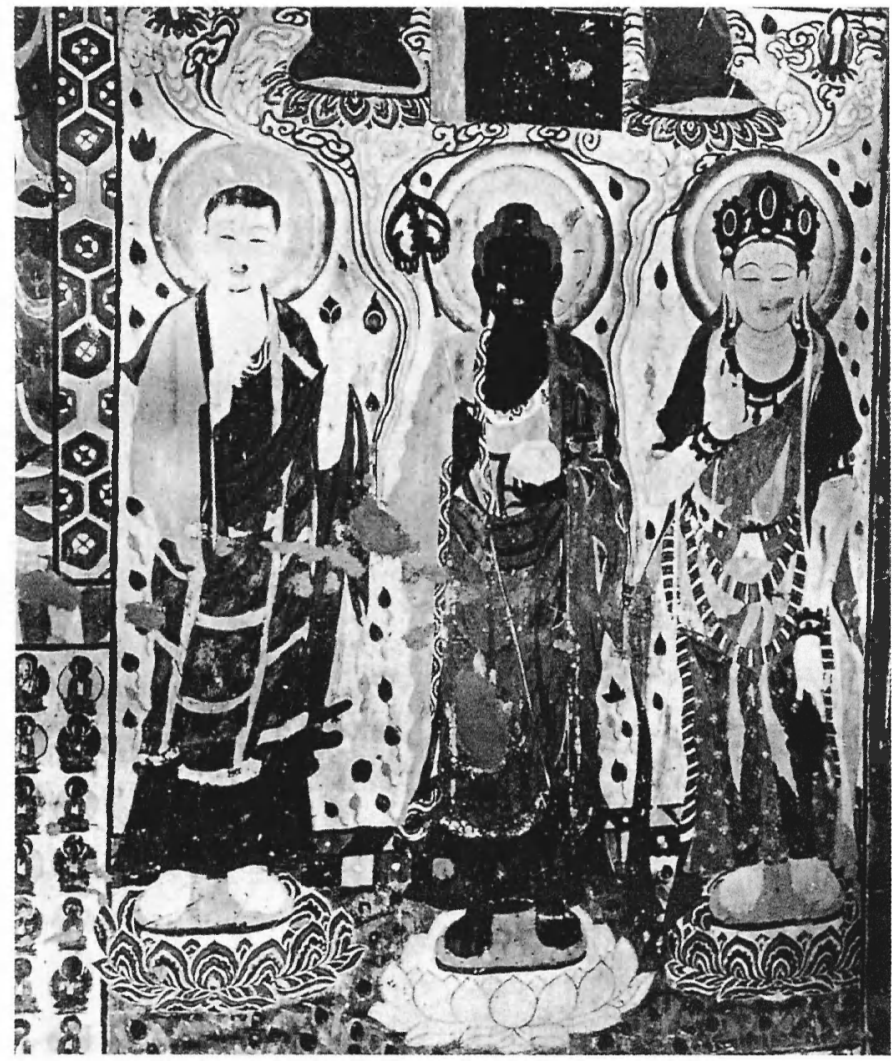

Fig. 8. Jizō, Yakushi, Kannon. Cave 205, Dunhuang, China. Tang dynasty, $8^{\text {th }}$ c. From Roderick Whitfield and Anne Farrer, Caves of the Thousand Buddhas (London: British Museum Publications, 1990), p. I8.

as the eighth-century group of images in the Tōshōdai-ji kondō testifies. Although dissimilar to the Main Image and the Sanbonmatsu Jizō in general appearance, the Elevenheaded Kannon displays a comparably high level of craftsmanship. Stylistically, the Main Image, the Sanbonmatsu Jizō, and the Eleven-headed Kannon seem to be of approximately the same date, the late ninth to the early tenth century, and are among the finest existing pieces of early Heian-period sculpture. They are reasonably congruous in size, and in the absence of a more compellingly appropriate image, I propose that the third member of the triad was the Eleven-headed Kannon at present in the kondō. ${ }^{17}$

\section{ICONOGRAPHY OF THE TRIAD}

Before discussing the combination of Yakushi, Jizō, and Kannon in iconographic terms, we should recall that the usual flanking images in a Yakushi triad are Nikkō Bosatsu (S: Sūryaprabha Bodhisattva) and Gakkō Bosatsu (S: Candraprabha Bodhisattva), respectively representing the light of the sun and the moon. These deities are normally depicted as plain bodhisattva figures, without extra appendages or specific identifying iconographical traits.
Examples include the flanking images at Yakushi-ji (eighth c.), Daigo-ji (Engi I 3 [9I3]), and Kachio-ji (late ninth-early tenth c.).

\section{CHINESE SOURCES}

Though unusual in Japan, the combination of Yakushi, Kannon, and Jizō is not without precedent. Asai Kazuharu has investigated the various iconographic groupings incorporating images of Jizo, and the following discussion, beginning with Chinese prototypes for the combination of Jizō, Kannon, andYakushi, is indebted to his work. ${ }^{{ }^{8}}{ }^{\text {Kakuzensho }}$ (Kakuzen's Notes; I I76-1219), an iconographic compendium by the monk Kakuzen, in its Doji KYö (S: Kumāra Sütra) section, describes a mandala that contains the combination of Yakushi, Kannon, and Jizō. ${ }^{19}$ This Döji mandala, the text states, is of proven efficacy in the rites for childbirth. In this mandala Yakushi takes the form of the second of the Shichibutsu Yakushi (the seven transformed bodies of Bhaisajyaguru), who vows to facilitate childbirth (the third of the eight great vows of Yakushi). ${ }^{20}$ Because it includes other divinities as well, the Dōji mandala does not precisely match the proposed Murō-ji triad. It does make clear, however, that Yakushi, Kannon, and Jizo, in combination, were believed to facilitate childbirth.

In Chinese belief the Bodhisattvas of Light (J: Hōkō Bosatsu), as represented by Kannon and Jizō, were often thought to play a part in facilitating childbirth. Kobayashi Taichirō, who has carefully investigated this subject, has concluded that one of the earliest references to the Bodhisattvas of Light is found in Asabasho. The section of Asabasho entitled "Hōkō" ("Light"), quotes a Chinese text (Fangguang Pusa Ji; J: Hokō Bosatsu Ki; Records on the Bodhisattvas of Light) as stating that certain miraculous images of Kannon and Jizō from Shanji-si in Hanzhou of central China are said to facilitate childbirth. ${ }^{21}$ Paintings of Jizō and Kannon by the celebrated Liang-dynasty (502-557) painter Zhang Sengyou were copied several times, because they were said to emit a miraculous light that overcame perils on the sea and in childbirth. ${ }^{22}$ In one fantastic tale in Asabasho, dated Daili I (766) of the Tang dynasty (6 I 8-907), a woman who had been pregnant for twenty-eight months finally gave birth to a son on the night the paintings were copied. The somewhat earlier Kakuzensho, in the first part of the chapter devoted to Shō Kannon (S: Ārya Avalokiteśvara), also mentions a Tang-dynasty wall painting, at a temple known as Kaiyuan-si, showing Jizō and Kannon together, noting that lay people called the pair Bodhisattvas of Light and credited them with helping women in childbirth. ${ }^{23}$

Augmenting these textual sources, the Dunhuang caves of northwestern China contain several representations of Jizō and Kannon together. Of particular significance to this discussion is an eighth-century painting from Cave I66, with Kannon standing at viewer's left and Jizō at viewer's 
Fig. 9. Niche with flanking Jizō and Kannon paintings. Cave 45 , Dunhuang, China. Tang dynasty, $8^{\text {th }} \mathrm{c}$. Photograph courtesy of The Lo Archive.

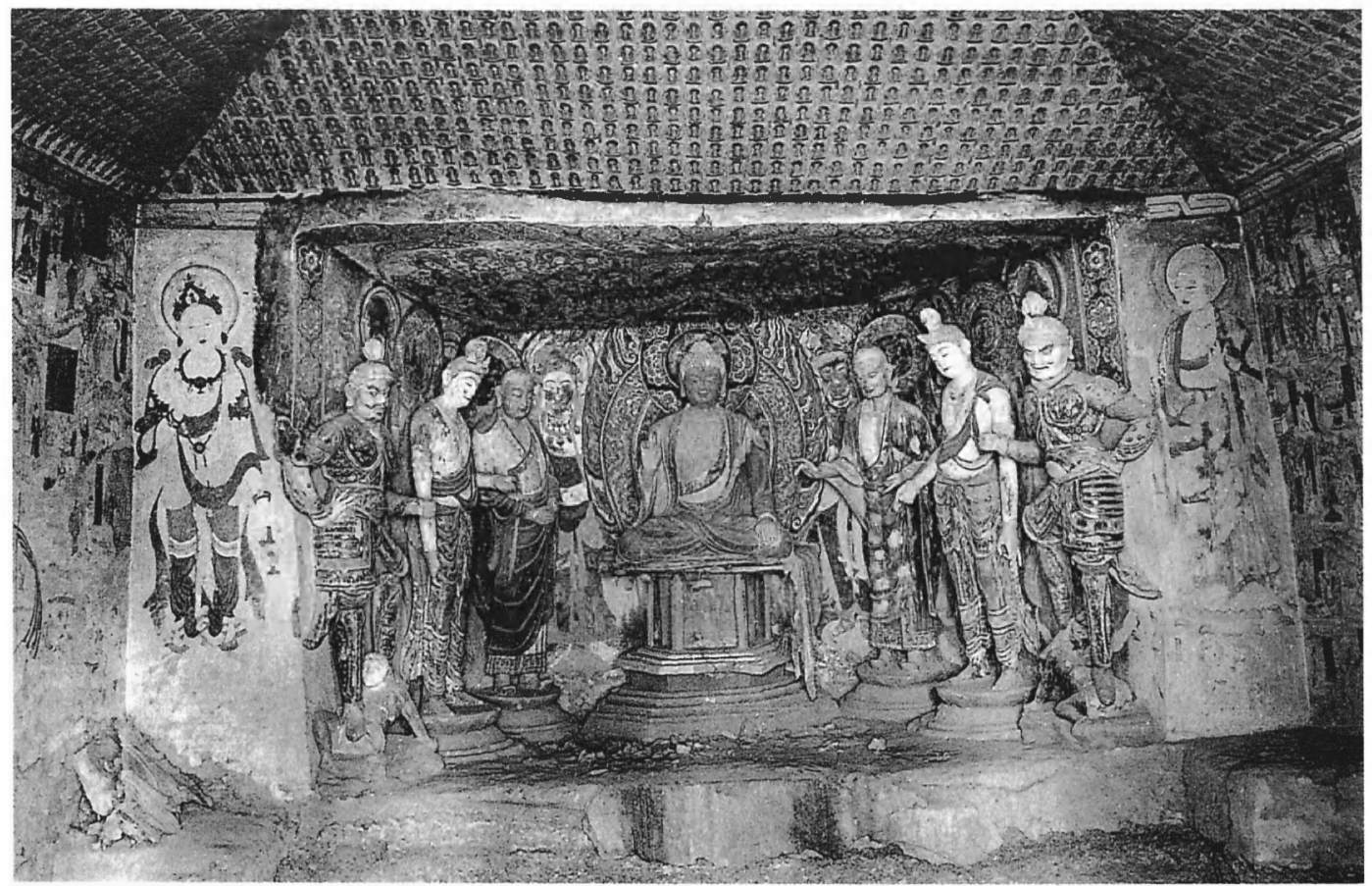

right; a cloud emanating from Jizō's right hand supports seven seated Buddhas. ${ }^{24}$ Presumably these are the Shichibutsu Yakushi, the seven transformed bodies of the Healing Buddha, Bhaișajyaguru, mentioned above; if so, they complete the composition by including Yakushi as a deity pertinent to this pair of bodhisattvas. At Dunhung Asai found nineteen representations of Kannon and Jizō together and six of Jizō and Yakushi together, all dating from the eighth through the ninth centuries. ${ }^{25}$

More significantly, Caves 176 and 205, of the eighth century, contain triads of Kannon, Yakushi, and Jizō. ${ }^{26}$ In Cave 205 this triad formation, dating from the mid-eighth century, is painted on the south wall below a paradise scene (Fig. 8). The Yakushi figure holds a medicine jar or bowl in the left hand and a monk's six-ringed staff (J: shakujo) in the right hand. Depicted above the triad are two monks holding incense burners, and above these are figures of Amida, two monks, Kannon, and Seishi (S: Mahāsthāmaprāpta). On the wall facing the triad is another paradise scene. Asai believes this triad of Yakushi, Kannon, and Jizō to be represented in paradise and states that these figures were enshrined to confer worldly benefit, to relieve the sufferings of sentient beings, and to ensure rebirth into a higher life. Since Yakushi, Jizō, and Kannon each have the power to aid in the achievement of worldly benefits, so the three together in combination could be expected to multiply the powers of each. ${ }^{27}$ Since all three specifically facilitate childbirth and Yakushi promotes health and healing as well, one might tentatively suggest that especially in this sphere the three together would multiply each other's efficacy. Among the many promises for healing in the Yakushi Sütra, the fol- lowing is particularly significant to this study: "If offerings are made to this Buddha [Yakushi] and his name is invoked, women in labour will be quickly released from pain. Their children will be born beautiful with perfect bodies and those who see them will rejoice. The children will have superior capacity, intelligence, calm dispositions, and few illnesses. Non-human beings will never be able to capture their spirits." 28

In I999 I was able to see some of these images in the Dunhuang caves, including those in Cave 205, and to discover other examples in which Kannon and Jizō are prominently paired. Cave 45 , best known for its elegant clay sculptures in the central niche, which are judged to date from the High Tang period (705-780), has two life-size paintings of Kannon and Jizō flanking that niche, on viewer's left and right, respectively (Fig. 9). ${ }^{29}$ The paintings date from a subsequent restoration of the cave during the Middle Tang period (78I-847), and can be assumed to have been added to enhance the beneficial efficacy of the sculptured icons in the niche. The latter constitute a standard grouping, with Shaka flanked by two disciples, two bodhisattvas, and two guardian deities. In Cave 172 , dating from the High Tang (705-780), a large Jizō and Kannon are painted on the upper section of the east wall. Among many other painted images in the cave,Yakushi appears at the top of the north wall, providing another example of the three images in the same worship space. ${ }^{30}$

More recently, other sites besides Dunhuang have revealed groupings that include the deities Kannon, Jizō, and Yakushi. Henrik Sorenson has noted that paired images of Kannon and Jizō are common in Sichuan, citing as examples the 


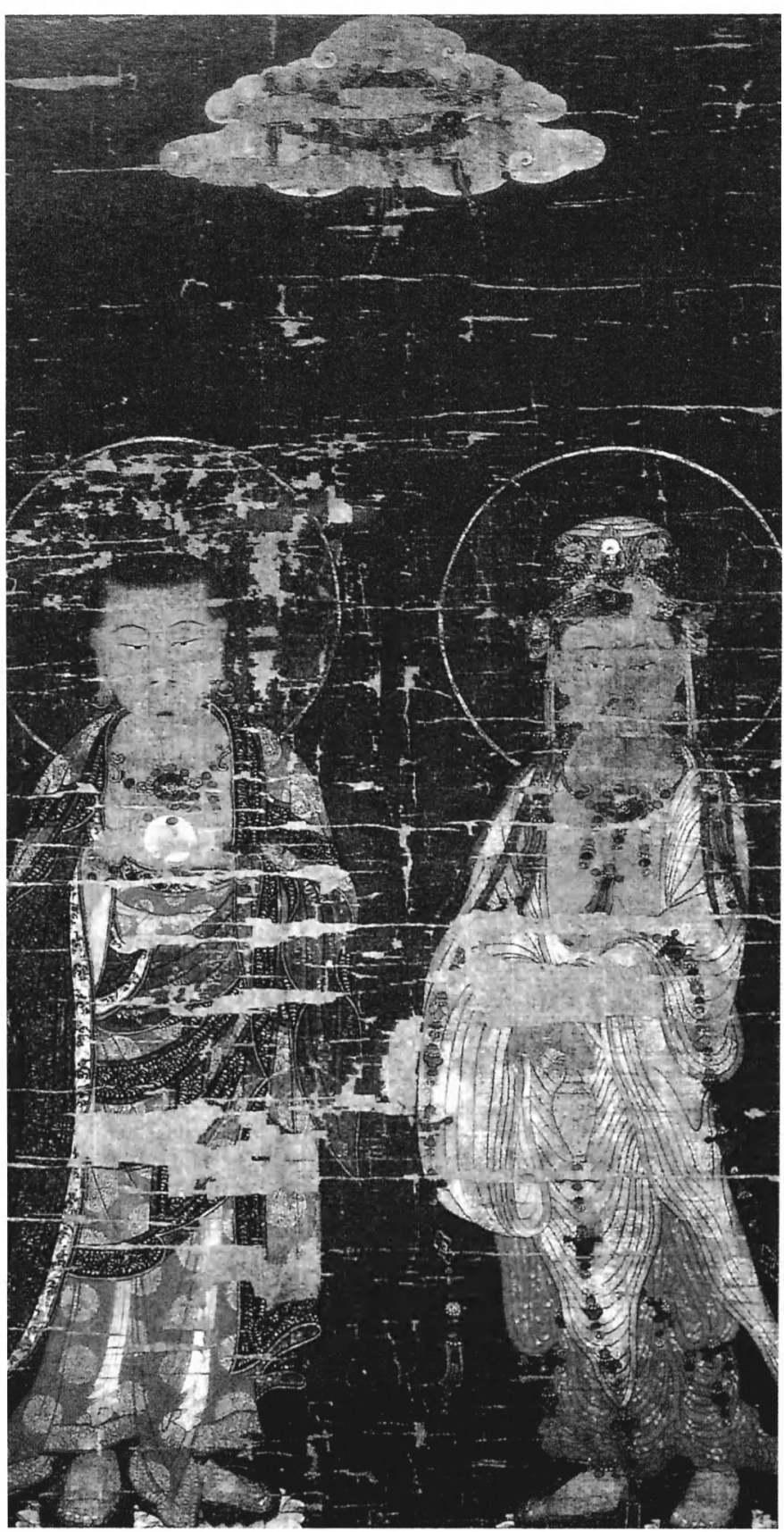

Fig. Io. Kannon and Jizō. Saifuku-ji,Tsuruga, Fukui Prefecture. Koryŏ dynasty (918-I392). Hanging scroll; ink and color on silk; h. $99.0 \mathrm{~cm}$, w. $52.2 \mathrm{~cm}$. From Ho-am Art Museum, Koryŏ, Yŏngwŏnhan Mi: Koryŏ Purhwa T'ukpyŏljŏn (Seoul: Samsung Misul Munhwa Chaedan, I 993), cat. 20, p. 73 .

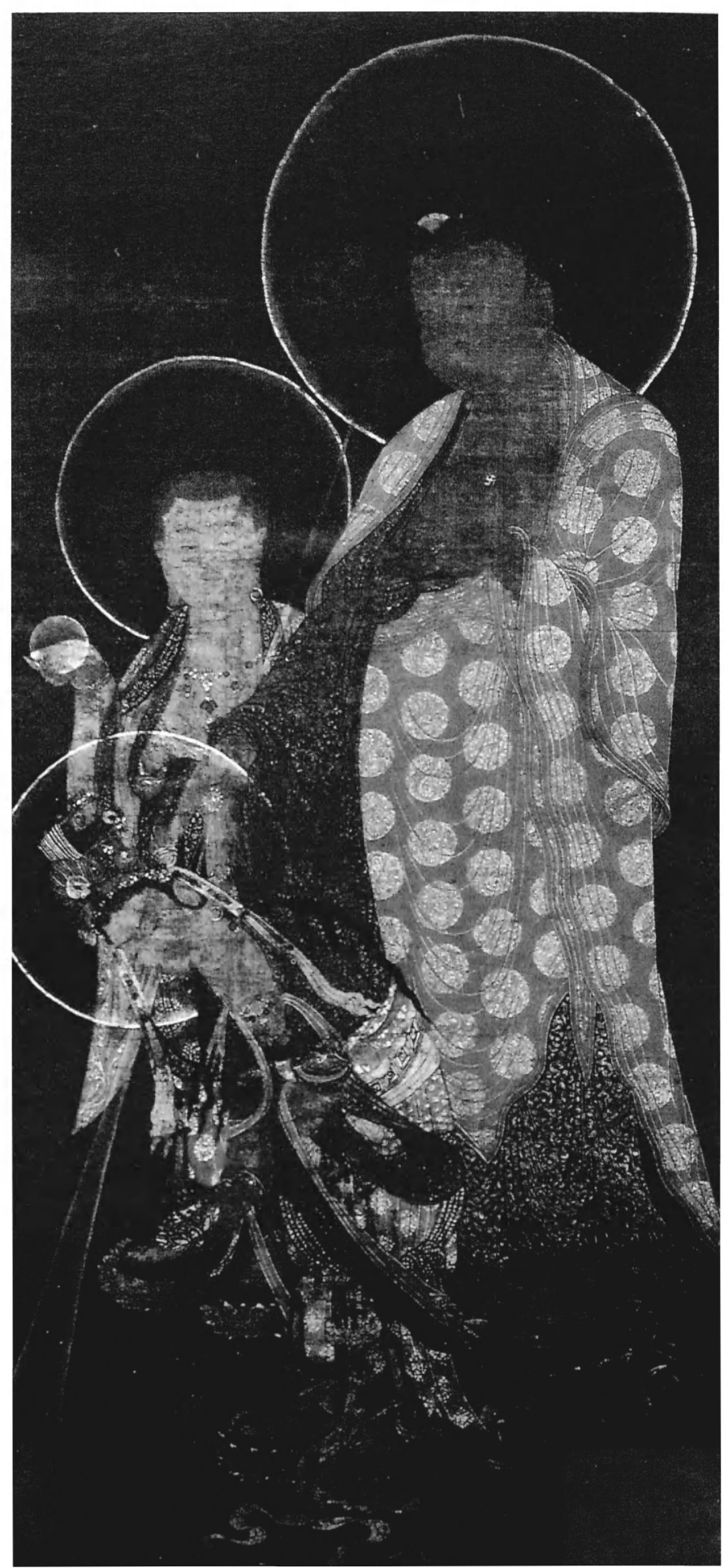

rig. I I. Jizō, Amida, Kannon. Fourteenth c. Hanging scroll; ink and color on silk; h. I $10.0 \mathrm{~cm}$, w. $51.0 \mathrm{~cm}$. Ho-am Art Museum, Yongin, Korea. From Ho-am Art Museum, Koryŏ,Yŏngwŏnhan Mi: Koryŏ Purhwa T'ukpyŏljön (Seoul: Samsung Misul Munhwa Chaedan, I993), cat. I I, p. 43. Photograph courtesy of Ho-am Art Museum. 
Fig. I 2. Shaka triad. Ōya-dera, Utsunomiya city, Tochigi Prefecture. Io ${ }^{\text {th }} c$. Stone; h. of central image $354.0 \mathrm{~cm}$. From Kuno Takeshi, Sekibutsu; vol. 36 of Book of Books, Nihon no Bijutsu (Tokyo: Shōgakkan, I975), pl. 42, p. 57. Photograph courtesy of Shōgakkan.

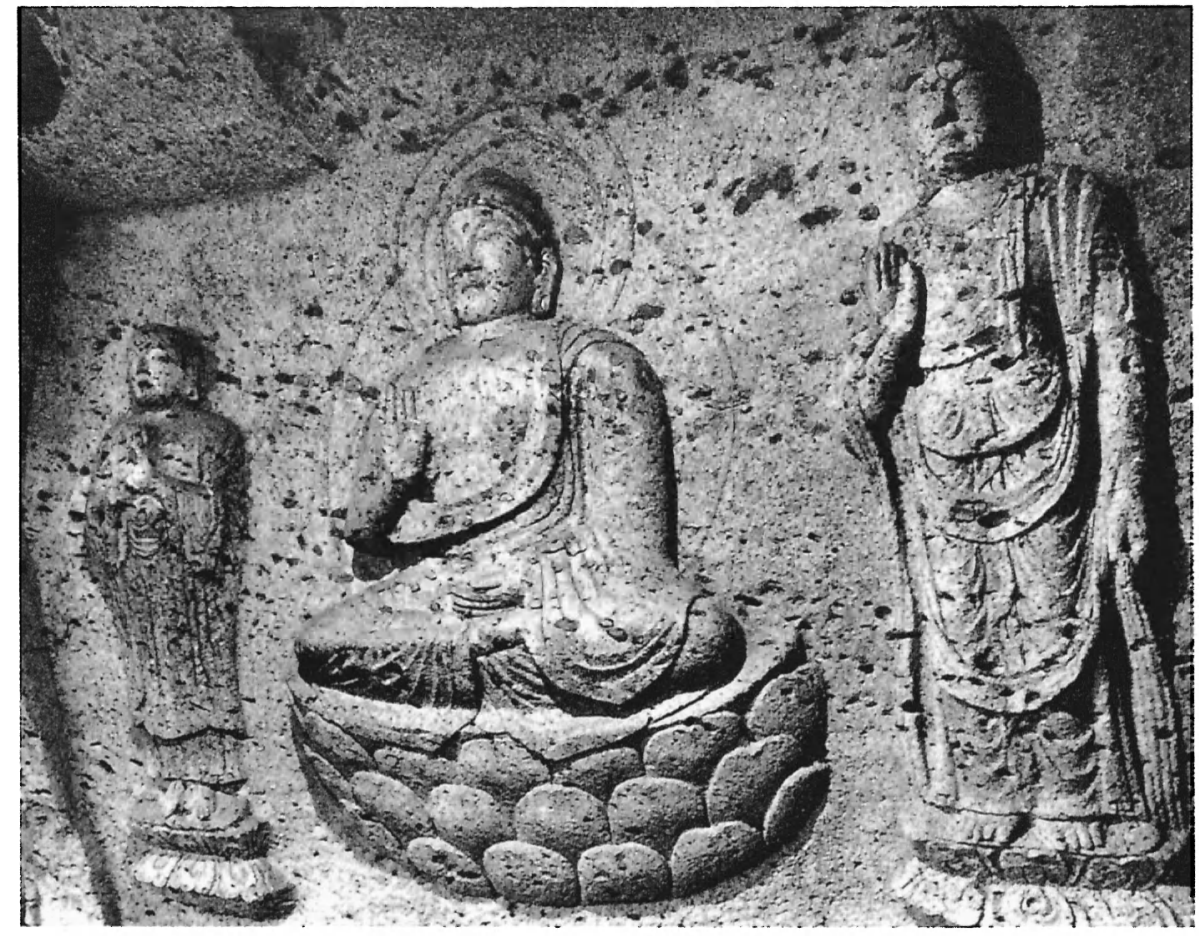

eighth-century sculptures at Feixian Pavilion in Pujiang ${ }^{1}$ and an eighth-century grouping of Kannon, Jizō, and Amida in Jiajiang. ${ }^{32}$ Another scholar, Zhiru, also investigating Buddhist sculpture in Sichuan, has found many groupings that include Kannon, Jizō, and Yakushi. ${ }^{33}$ The expanding number and geographical range of examples provide additional evidence that Japanese student- and pilgrim-monks would have found an abundance of sources to inspire them to transplant such a triad configuration in Japan.

\section{KOREAN SOURCES}

Some interesting extant images from Korea further attest the widespread prominence of the Bodhisattvas of Light in East Asia. Saifuku-ji in Tsuruga, Fukui Prefecture, Japan, owns a fine Korean painting depicting Kannon and Jizō standing side by side beneath a small canopy (Fig. 10). The painting dates from the Koryo dynasty (918-1392), postdating the Murō-ji sculptures and demonstrating a continuing Asian belief in the efficacy of the pair. ${ }^{34}$ Another impressive Korean painting from the fourteenth century in the Ho-am Art Museum shows the two bodhisattvas together with a Buddha (Fig. 11). Jizō, holding a jewel, stands to the right of Amida Buddha, while in the foreground Kannon bends down to greet an aspirant. Here Jizō replaces Seishi Bosatsu, who usually accompanies Amida and Kannon in scenes of welcome to the Pure Land (J: raigö). Junghee Lee postulates that Jizō's presence here reflects his particular importance in Korean Buddhism during this period, ${ }^{35}$ but the grouping may also have been created to promote the cult of the Bodhisattvas of Light.

\section{JAPANESE SOURCES}

Tenth-century Japanese records afford plentiful evidence of Jizō and Kannon images in combination. Tödai-ji Yoroku (Principal Records of Todai-ji), compiled by the monk Kangon (I ISI-I 236), records that a daughter of a palace attendant had statues of Kannon and Jizō enshrined in the Kanjō-in at Tōdai-ji in Engi 4 (904). ${ }^{36}$ The Tendai document Mon'yoki (Record of the Gate of Leaves) also records tenth-century pairings of Jizō and Kannon images. ${ }^{37}$ And according to Fujiwara no Morosuke (908-960), in Tenryaku 8 (954) images of Kannon, Seishi, Jizō, and Ryūju (S: Nāgārjuna) were enshrined in the Jōgyōdō ("Hall for Constant Practice") located at the Hokke Zanmaido ("Lotus Meditation Hall") complex in the Yokokawa area on Mt. Hiei. ${ }^{38}$ The same four divinities, centered around a golden Amida at Tōdai-ji, are mentioned in Tödai-ji Yöroku, in an entry for Eiso 2 (989), third month, nineteenth day; the entry relates that this pentad was meant to represent the entire universe (jitahokai). ${ }^{39}$ The actual sculptures have been dispersed or destroyed, but these passages serve to show that Kannon and Jizō images were often placed together in tenth-century Japan.

Determining the original makeup of a sculptural group is difficult, because freestanding sculptures can be-and often were-moved. Therefore in Japan I have searched for extant unchangeable groupings of Kannon and Jizō with a Buddha, such as paintings and stone relief images. Groupings of sculptural icons do not always conform to specific texts, but may reflect the preferences or needs of a particular temple or worship space, or even the chance preservation of specific images. No triad of Yakushi, Jizō, and Kannon has 


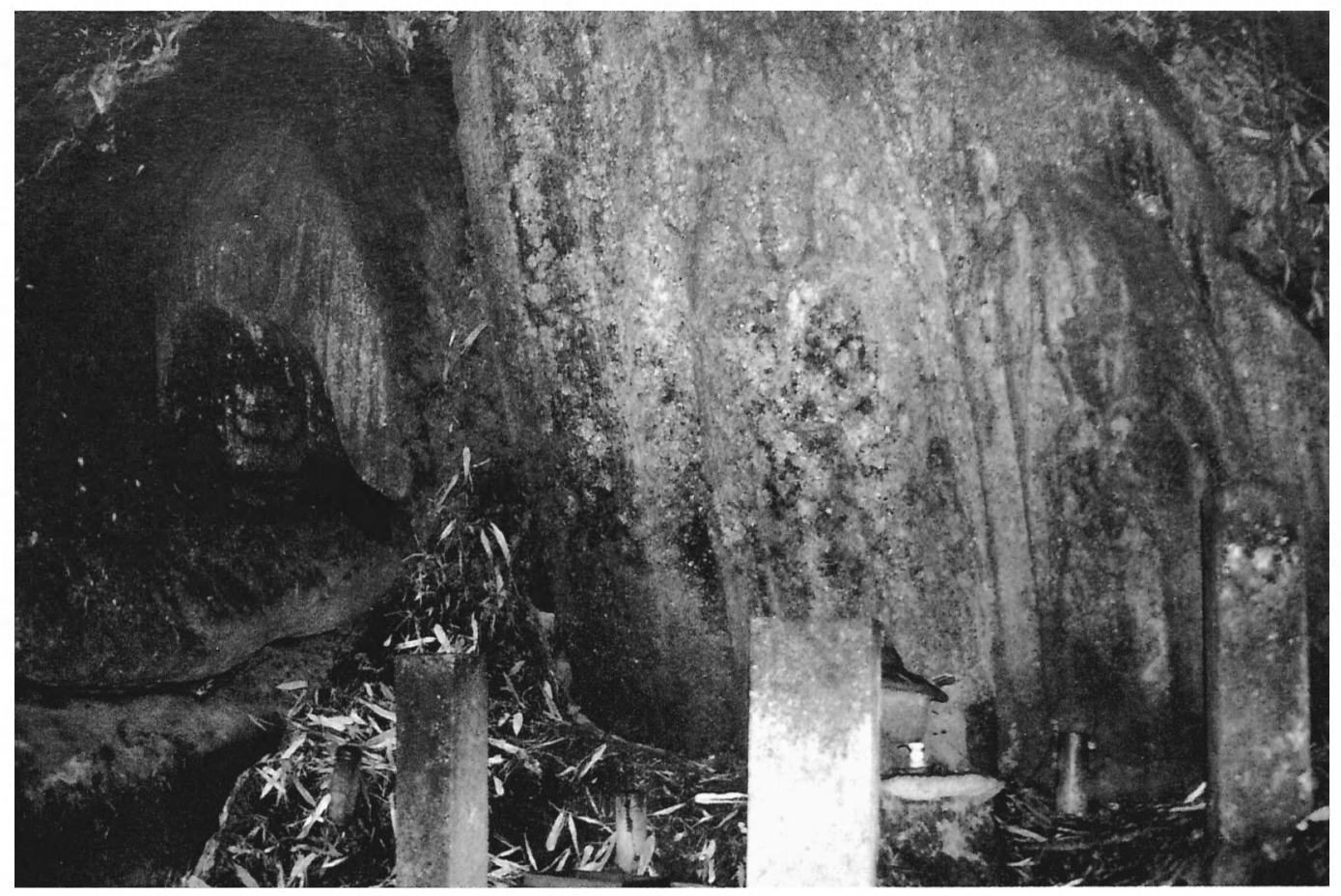

Fig. I 3. Tachibana Anjō (act. late I $3^{\text {th }}$ c). Jizō, Eleven-headed Kannon, and Amida. Tōnoo, Kyoto Prefecture. Dated Kōchō 2 (I262). Stone. Photograph by author.

yet been found in Japan, but I will offer some examples of variant but related combinations.

At Ōya-dera in Utsunomiya city, Tochigi Prefecture, is an interesting group of stone relief images, all in triads, thought to date from the tenth century. In two of the three secondary niches the central Buddha is flanked by a Kannon image at proper left and a figure of a monk with hands in the gesture of prayer (gassho) at the right (Fig. 12). Although no inscription or other documentation confirms the identification, the monk figure may well represent Jizō. $4^{\circ}$

Between Jōruri-ji and Gansen-ji in Kyoto Prefecture, in a rural area called Tōnoo, many old stone images have been left largely undisturbed. Among them, in the open, is a triad of Jizō, Eleven-headed Kannon, and Amida, carved in stone relief. ${ }^{1}$ In this triad, known as the "Yabu no naka sanzon" ("Triad in the thicket"), Amida is seated at proper right, Jizō stands in the middle, and a much shorter Eleven-headed Kannon stands at left (Fig. 13). ${ }^{42}$ In a typical triad format, Amida would be the central figure, but the coarse texture of the granite and the natural shape of the boulder must to some degree have determined the unusual disposition of the images. An inscription on Amida's proper right names the artist as Tachibana Anjō and gives the date of Kōchō 2 (I262). ${ }^{43}$

The Kamakura period affords other examples of triads consisting of Kannon, Jizō, and a Buddha. ${ }^{44}$ Space does not permit an exhaustive list, but I should like to mention Asami Ryūsuke's intriguing discussion of several such groupings, in course of his investigation of a thirteenth-century triad formerly located at Kichiden-ji in Izu, Shizuoka Prefecture. 45 Asami explains the groupings, including the proposed triad of the Murō-ji images, as prompted by the belief in Hōkō
Bosatsu, but hypothesizes also that such triads were created to enlist divine aid for water control, whether of drought, flooding, or dangerous currents. Supporting that hypothesis, Asami found that two of the images in his study had written prayers for rain $(k y \bar{u} u)$ inserted inside them. ${ }^{46}$ Murō-ji, with its long history of rain prayer, supports this model. Asami himself, however, considers his theory only tentative, and the evidence for it far from conclusive.

I have presented the preceding as evidence to support my hypothesis that a triad consisting of Yakushi, Jizō, and Kannon, although admittedly unusual, might have been installed in the Murō-ji kondō. All three deities were popular individually in the Heian period, as shown by the numerous extant representations of each. Kannon and Jizō, together called the Bodhisattvas of Light, were worshipped in China, Korea, and Japan as conjointly powerful in their facilitation of childbirth, as recorded in documents such as Asabasho and Kakuzenshō. Their paired images occur in paintings as well as in sculpture. Adding Yakushi, the Buddha of Healing, who also promises to aid in childbirth, must have been credited with a synergistic effect, and would have certainly magnified the belief in the efficacy of prayers directed toward each of them.

\section{HONJI-SUIJAKU AND MANIFESTATIONS OF THE KASUGA DEITIES}

Even if the current pentad was not original to the Murōji kondō altar, we must ask how these five images came to be located there and how they have been interpreted. Currently referred to as Shaka, Yakushi, Jizō, Eleven-head- 
ed Kannon, and Monju, the five sculptures compose a group which I have not yet found in Buddhist sūtras, commentaries, or any other complete extant sculptural arrangement. One theory concerning this assembly of deities is that they represent the honji ("original ground") of the deities of Kasuga Shrine in Nara. Essentially this idea is based on a Buddhist-inflected concept commonly referred to as honjisuijaku, in which each Buddhist deity was considered a honji, and a kami, or "Shinto" deity, was considered that honji's suijaku ("trace" or "manifestation") - a concept that clearly accords primacy to the Buddhist deities. In recent scholarship on Japanese religion there have been attempts to redefine Shinto, a problematic term on two counts: on the one hand it is associated with a pernicious nationalism of the post-Edo period, and on the other it implies, falsely, a coherent system based on ancient shrine rituals. I shall use the word Shinto to refer to the worship of and dealings with kami, the non-Buddhist divine beings primarily connected to shrine worship. Honji-suijaku, which allows a manifest kami to be worshipped at a Buddhist temple, illustrates the fluidity of Japanese religious practice.

According to Allan Grapard, in the honji-suijaku system Buddhist divinities are said to assume the forms of kami in order to guide the various types of sentient beings toward the realization of Buddhahood. ${ }^{47}$ The matching of honji to suijaku was by no means fixed; many variant identifications existed within the same time period and location, and it was possible for one suijaku to pertain to several honji. The concept is commonly thought to have originated in the tenth century; by the twelfth century correspondences between kami and Buddhas were becoming more and more precise. ${ }^{4}$ Honji-suijaku should be distinguished from the concept of shinbutsu-shīgo, a broader term referring to the early unification of gods and Buddhas which began immediately after the inception of Buddhism in India. An example of shinbutsu-shūgō is the transformation of the Hindu deities Indra and Brahma into guardians of Buddhism called Taishakuten and Bonten respectively. In general and despite many variations, the honji-suijaku system embodies a more exact and specific matching of Buddhist and Shinto deities than the more general amalgamations of shinbutsu-shūgō.

In Meiji I (I 868) the Japanese government initiated a program of separating temples and shrines (shinbutsu-bunri) by extracting elements considered to be Buddhist from shrines and elements considered to be "Shinto" from temples. ${ }^{49}$ Scholarship antedating the Pacific War has continued to bias research on the relationships of Buddhist deities and kami by perpetuating that early Meiji dissociation of the two. ${ }^{50}$ More recently, however, scholars such as Allan Grapard and Susan Tyler have made efforts to envisage the historical and doctrinal integration of Buddhism and Shinto. ${ }^{\mathrm{II}}$ In addition, the study by Ian Reader and George Tanabe offers yet a different perspective: it looks at honji-suijaku from the standpoint of its practitioners, who prayed to a kami or a Buddhist deity

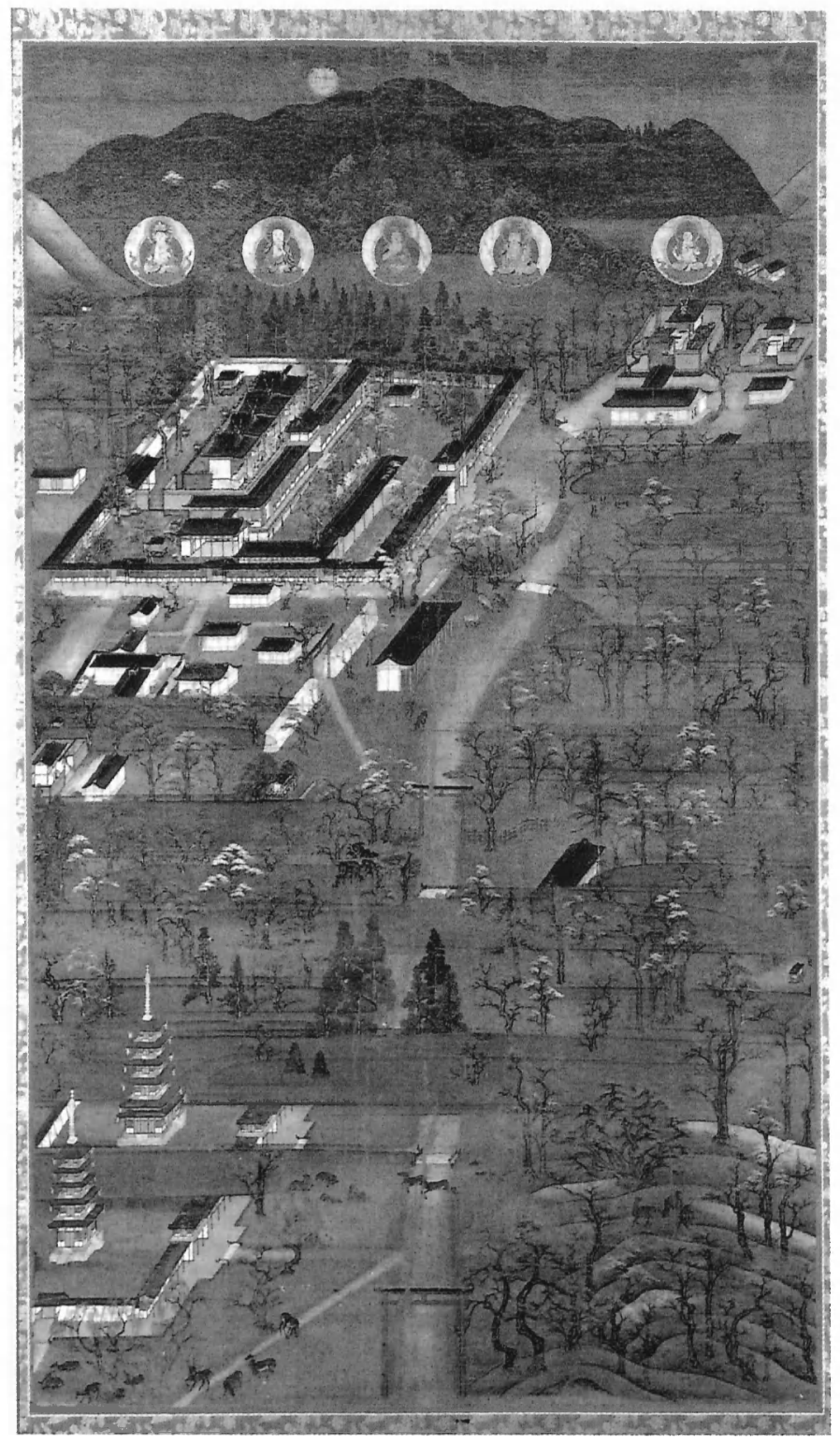

Fig. I4. Kasuga Mandala. Minami'ichi-chō, Nara. $14^{\text {th }}$ c. Color on silk; h. I $83.3 \mathrm{~cm}$, w. $106.3 \mathrm{~cm}$. Photograph courtesy of Nara National Museum.

as a means to obtain certain benefits, indifferent to exact correspondences or hierarchical distinctions between them. ${ }^{52}$ Following this path, I shall examine the physical evidence of sculpture to explore how the corresponding deities of honjisuijaku were manifested in objects of worship.

\section{KASUGA CONNECTIONS WITH MURŌ-JI}

Although they stand about $\mathrm{I} 20$ kilometers apart, there is a significant historical connection between Murō-ji and Kasuga Shrine in Nara city, a shrine that had its own par- 


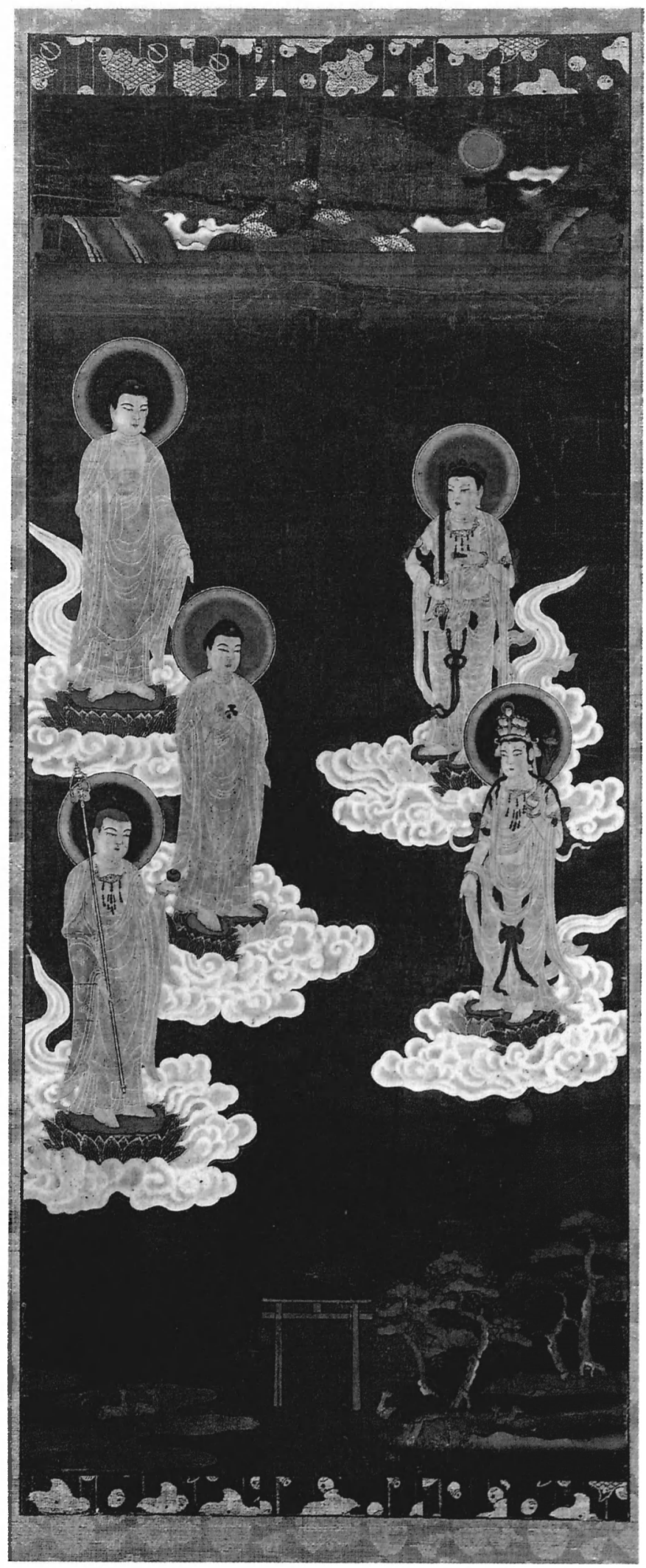

Fig. I s. Kasuga Honji-butsu Mandala. I $5^{\text {th }}$ c. Hanging scroll; ink and color on silk; h. $85.2 \mathrm{~cm}$, w. $37.3 \mathrm{~cm}$. Asian Art Museum of San Francisco. Photograph courtesy of Asian Art Museum of San Francisco, The Avery Brundage Collection, 1991.59. ticular set of deities. Kasuga Shrine and the adjacent Kōfuku-ji were formerly linked as components of a great shrine-temple complex, in which Murō-ji figured as a subtemple of Koffuku-ji until the late seventeenth century.The five deities on the altar in the Murō-ji kondo correspond to the kami at Kasuga. The latter reside, respectively, in four small buildings at Kasuga Shrine aligned at the rear of the main sanctuary plus a fifth small building, built in Hōen I (II35), located to the south and outside of the main precinct. The buildings (designated by number), their resident kami, and the Buddhist honji of these are as follows:

(I) Ichinomiya ("First Shrine") / Takemikazuchi = Shaka Nyorai

(2) Ninomiya ("Second Shrine") / Futsunushi =Yakushi Nyorai

(3) Sannomiya ("Third Shrine") / Amenokoyane $=$ Jizō Bosatsu

(4) Shinomiya ("Fourth Shrine") / Himegami = Eleven-headed Kannon Bosatsu

(5) Wakamiya (Fifth Shrine, named for its resident kami, Wakamiya ["Young Prince"])

= Monju Bosatsu

Collectively, the five kami are known as Kasuga Daimyōjin. Allan Grapard gives a detailed account of the honji-suijaku correspondences of the Kasuga Daimyōjin and of the possible rationales for the specific correspondences. ${ }^{53}$ Plainly, the current alignment of images on the Murō-ji kondō altar does not follow the numeration of the shrine buildings at Kasuga, doubtless because in groups of sculptured icons the image of the highest rank and greatest size was traditionally placed in the center.

In sculptural form, no other complete set exists of the Kasuga honji-butsu (honji-suijaku deities manifested in Buddhist form), but they are depicted as a group in a number of extant paintings, the earliest dating from the Kamakura period (I I 85-I 333). Painters found a way to represent the deities' dual identities explicitly. In one of the earliest paintings of the Kasuga Shrine mandala, dated Shōan 2 (I 300 ), by the artist Kanshun, the Buddhist deities hover above each corresponding shrine building in an arrangement which exactly matches the Murō-ji lineup of Kannon, Monju, Shaka, Yakushi, Jizō (from proper right to left). ${ }^{54}$ Another Kasuga Shrine mandala of the fourteenth century, from Minami'ichi-chō, Nara, shows the same five Buddhist deities, each framed in a circle of light, levitating above the shrine landscape-again, an explicit demonstration of the dual identities of the deities (Fig. 14). ${ }^{55}$ The same group appears in a beautiful fifteenth-century painting in the Packard Collection of the Asian Art Museum of San Francisco, in which the five deities hover on clouds above a torii gate and deer, which together specify the Kasuga Shrine precinct (Fig. 15). ${ }^{56}$

The diary of the Kōfuku-ji prelate Jinson (1430-I 508), Daijo-in Jisha Zojiki (Notes of the Daijo-in [Subtemple of 
Kōfuku-ji] on Various Matters of the Shrine/Temple Complex), includes an entry dated Kanshō 2 (I 46I), ninth month, fourteenth day, regarding other group representations of the five Kasuga honji-butsu that have since been lost. ${ }^{57}$ Daijo-in Jisha Zöjiki mentions a small temple whose thirteen-story pagoda and Hokkedō ("Lotus Sūtra hall") each enshrined sculptures of these five Kasuga honji-butsu. That temple was the Shion-in, to the west of Mt. Wakakusa in Nara, affiliated with Kasuga and with the Daijō-in of Kōfuku-ji. ${ }^{8}$ The Shion-in was built in Kenpō 3 (I215) and burned in Bunmei I2 (I480); rebuilt, it survived into the eighteenth century. ${ }^{59}$ Daijo-in Jisha Zojiki contains drawings of the interiors of the two buildings, showing both of them to contain Shaka,Yakushi, Jizō, Kannon, and Monju, as at Murō-ji. ${ }^{60}$ In each building Shaka was enshrined in the center of a square altar, with the others at the four corners. Apparently the walls bore paintings of paradise and welcoming scenes that also included the Kasuga honji-butsu. ${ }^{6 \mathrm{I}}$ These two Shion-in altar groups, with their relationship to Kasuga and Kōfuku-ji, and explicitly identified in Daijo-in as Kasuga honji-butsu, support the idea that the identical group at Murō-ji, as a subtemple (matsuji) of Kōfuku-ji, could also represent the Kasuga honji. ${ }^{62}$

Recently a thirteenth-century sculpture of Monju (Fig. 16) owned by the Tokyo National Museum was published for the first time. ${ }^{63}$ Yamamoto Tsutomu argues convincingly that this image of Monju once belonged to a set of Kasuga honji-butsu, and may even be one of the original icons from the thirteen-story pagoda of the Shion-in. ${ }^{64}$ An Eleven-headed Kannon image now in the Nara National Museum (dated to I22I) and a Jizō image in the Asia Society Collection in New York (dated to I 223-I 226) were found to be extremely similar in proportion and style to the Tokyo National Museum Monju image. Inside their body cavities, the Kannon and Jizō images each bear lengthy inscriptions, similarly phrased, that identify the sculptor as Zen'en, include prayers for protection by the Kasuga deities, and record the name of the Kofuku-ji prelate Han'en ${ }^{65}$ These references directly link the images as honji-butsu to the Kasuga/Köfuku-ji complex. The Monju image, with its youthful face and characteristic five topknots, should also be considered a work by Zen'en (I I97-I 257), made at the same time as the Kannon and Jizō. Although these three images are the only ones known of a putative set of five, they nevertheless offer additional compelling evidence that several groups of the five Kasuga honji deities were constructed in sculpture, thus proving that the assemblage at Murō-ji was not unique. ${ }^{66}$

One of the earliest sources to name the honji-butsu of the Kasuga Daimyōjin is a Kasuga document dated Joan 5 (I I75), written by the head monks of the Shinomiya and Wakamiya shrines. ${ }^{67}$ Their correspondences are almost identical to those I have posited for the Murō-ji figures, except they associate not Shaka but Fukūkensaku Kannon (S:

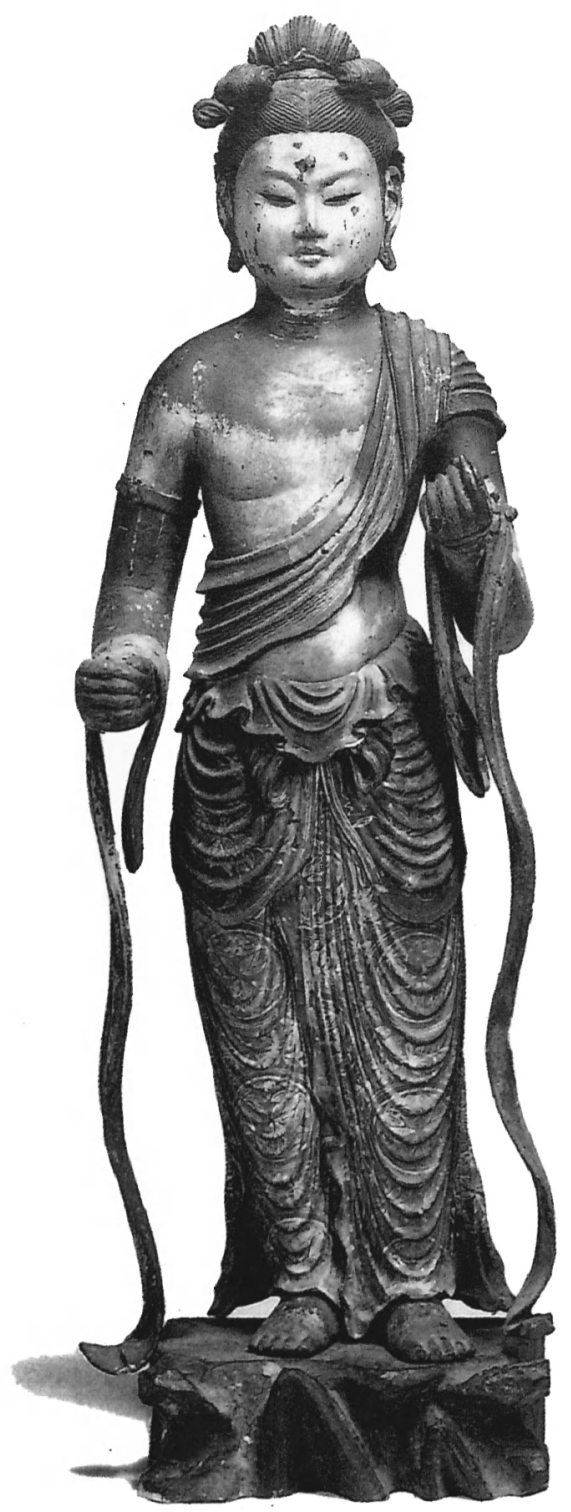

Fig. I6. Monju Bosatsu. $3^{\text {th }}$ c. Wood; h. $43.3 \mathrm{~cm}$. Tokyo National Museum. Photograph courtesy of Tokyo National Museum.

Amoghapāśa Avalokiteśvara) with the kami of the First Shrine (Ichinomiya). As mentioned earlier, the various lists of honji-suijaku are not wholly consistent. In Gyokuyo (Jewelled Leaves), the diary of Kujo Kanezane (I I49-I 207), an entry of Kenkyū 5 (I I94), seventh month, eighth day, gives yet a different list of Kasuga honji-suijaku connections, in which the First Shrine (Ichinomiya) corresponds to Fukūkensaku Kannon, both the Shinomiya and the Wakamiya correspond to Eleven-headed Kannon, and Monju is not mentioned. ${ }^{68}$ By the fifteenth century the two monzeki (temples headed by a prince-abbot) of Kōfuku-ji, Daijō-in and Ichijō-in, each proposed different lists of cor- 


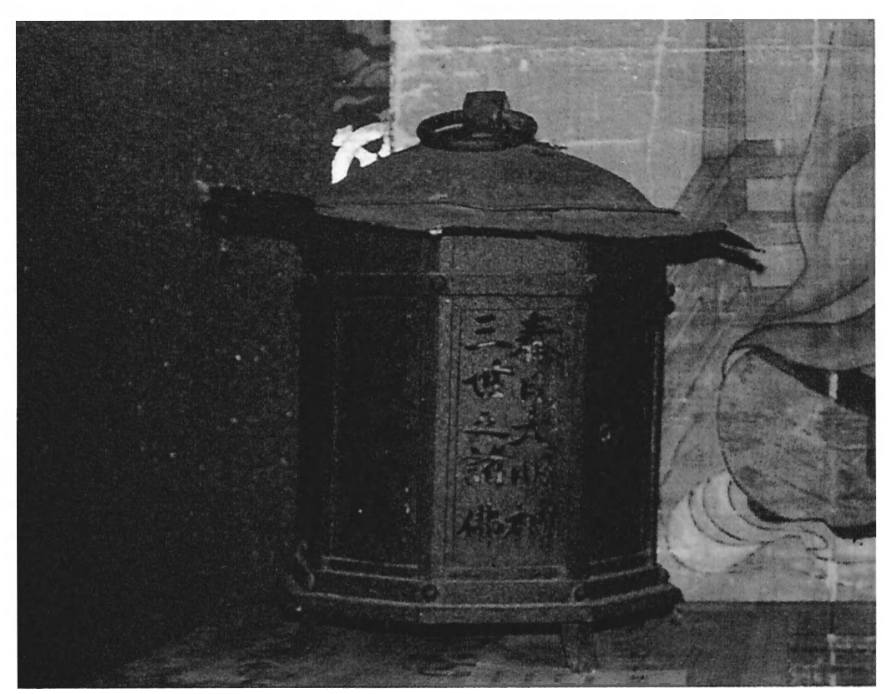

Fig. 17. Lantern. Murō-ji, Nara Prefecture. Keichō 4 (I 599). Iron; h. $39.0 \mathrm{~cm}$. Photograph by author.

respondences, both of which are recorded in Daijo-in Jisha Zöjiki.The Daijō-in list is identical with the Murō-ji group, ${ }^{69}$ suggesting that Murō-ji had a stronger relationship with Daijo-in than with Ichijo-in at the time the arrangement of the sculptures was conceived.

The earliest piece of physical evidence linking Murō-ji and Kasuga Shrine is an iron lantern (Fig. 17). This six-sided hanging lantern $(39.0 \mathrm{~cm})$ has a clear inscription, stating the following:

This lantern is dedicated at Mt. Murō in front of Kōbō Daishi’s jewel, to Zennyō Ryūō [Dragon King], Kasuga Daimyõjin, and all the Buddhas of the Three Worlds, for my parents, relatives, and the entire universe, by Yoshihide, from a small hall on Mt. Hachiman in Jōshū [Yamashiro, Kyoto Prefecture]. Keichō 4 [1 599], first month, twentyfirst day. ${ }^{70}$

Although the inscription does not specifically name the honji-suijaku deities, it clearly demonstrates that in the late sixteenth century the relationship between Murō-ji and the deities at Kasuga was recognized far beyond their immediate locale. Given that Kasuga is famous for its lanterns, this object made a particularly appropriate dedication.

Nagashima Fukutarō examined certain connections between Kasuga and Ryūketsu Jinja, the shrine on Mt. Murō, where, as at neighboring Murō-ji, Zennyō Ryūō was also worshipped. Ryūketsu Jinja was regarded as a subshrine (massha) of Kasuga and was periodically rebuilt by Kasuga. Nagashima also noted that inside the precincts of another Kasuga subshrine, named Kinosha, was a place with two stones where one could kneel and worship Murō from afar. $^{\text {I }}$

According to the I9I7 publication Nara-ken Uda-gun Shiryo (Material on the Uda District of Nara Prefecture), the prelate Kengyō (714-793) established a Kasuga Shrine in
Murō village for the purpose of protecting the Murō-ji kondō. ${ }^{2}$ This shrine no longer exists, having been incorporated into the Ryūketsu and Mizugami shrines in Meiji 4I (1908). ${ }^{73}$ Although the date of the founding of the Kasuga Shrine in Murō remains uncertain, the fact of its existence indicates strong connections between Murō and Kasuga. ${ }^{74}$ Another small Kasuga Shrine is located about seven kilometers from Murō village in the Sanbonmatsu area (site of the Sanbonmatsu Jizō), and records indicate that it was active in the Edo period (I615-1868). ${ }^{75}$ The existence of these Sasuga subshrines in the immediate vicinity of Murō-ji rdicates prevalent local devotion to the Kasuga cult.

\section{CONFLICTING HISTORIES AT MURŌ-JI}

The earliest documentary evidence relating Kasuga honjisuijaku theory to Murō-ji dates from the eighteenth century. Buzan Dentsuki (Chronicles of the Buzan Branch), a document made by the Buzan branch of the Shingon school, reports in a section dated Kyōhō 4 (I7I9) that Mt. Murō is called the "Kasuga Okunoin" (the inner sanctuary of Kasuga). ${ }^{76}$ In light of the bitter contest for control of Murō-ji between the Hossō and Shingon schools, it is surprising to find a Shingon document proclaiming Murō-ji's close relationship with Kasuga and hence with Kōfuku-ji, since Kōfuku-ji was a Hossō establishment. The dispute simmered from the sixteenth through the seventeenth century; each time a new head of the temple was to be appointed, the two factions struggled for the position. The Hosso monks of Kofuku-ji and their Shingon opponents from various temples went so far as to construct two competing written histories of Murō-ji, each highlighting circumstances that would bolster their claims. These histories along with other forms of evidence were submitted to the Shrine and Temple Magistrate for consideration. In Manji I (I658) the Magistrate decided in favor of Kofuku-ji, and the Shingon claims were disallowed. 77 Eventually, however, the combined influence of the wealthy female patron Keishoin (I624-I705) and the powerful prelate Ryūkō (I649-I724) succeeded in overturning that decision. Murō-ji was officially registered as a Shingon temple in Genroku I I (I698) and remains so today.

Between I658 and I698, Kōfuku-ji's final period of authority at the site, Kōfuku-ji's partisans at Murō-ji may have bent every last effort to strengthen their position on the ground. I propose that one head of the Koffuku-ji lineage of Murō-ji abbots decided to insert the Kasuga lineup of deities inside the kondō as a final effort to assert the Kasuga/Kōfuku-ji heritage. Using sculptures dating from the ninth and tenth centuries would have lent the group of five the sanction of age; no one at that time seems to have realized that these five Kasuga deities did not exist as a group until the twelfth century. ${ }^{78}$ As we have seen, the group of five at Murō-ji seems not to have been constitut- 
ed before the end of the seventeenth century. As evidence, Yamato Meishoshi, whose contents were probably being compiled in the latter part of the seventeenth century, mentions only three images in the hall, Shaka, Jizō, and Kannon, implying that the iconic grouping was only subsequently expanded to five. ${ }^{79}$

Mōri Hisashi and Mizuno Keizaburō, who noted the significance of the entry in Yamato Meishoshi, first published their results in $1976 .{ }^{80}$ Previously most scholars had concluded, based on the work of Kanamori Jun, that the five images had been placed in the kondo as representations of the Kasuga honji-butsu by the early Muromachi period (late fifteenth-early sixteenth century). ${ }^{8 \mathrm{r}}$

If the kondo altar held only three images instead of five at the time Yamato Meishoshi was being compiled, it is likely that it was about the end of the seventeenth century when the two other sculptures were added to create the full gathering of Kasuga deities and assert the authority of the Kasuga/Koffuku-ji complex. Once having achieved complete control over Murō-ji, the Shingon faction apparently felt it unnecessary to eradicate the relationship of Murō-ji to the Kasuga/Kōfuku-ji complex. Attempting to banish the Kasuga deities would, after all, have risked the wrath of the deities themselves and of their worshippers as well. In addition, Shingon temples tend to favor extremely complex iconic ensembles, and Shingon doctrine also included a honji-suijaku system.

Kobayashi Takeshi in I959 disputed the idea that the Murō-ji icons represented the Kasuga honji-suijaku. ${ }^{82} \mathrm{He}$ attempted to show instead that the five sculptures represented a sort of Yakushi mandala that is mentioned in Asabasho. According to his theory, the images are to be identified as follows:

Present name

$\begin{array}{ll}\text { Jizō } & =\begin{array}{l}\text { Kudatsu Bosatsu } \\ \text { (in the form of a disciple) }\end{array} \\ \text { Yakushi } & =\text { Miroku } \\ & \text { (in his form as a Buddha) } \\ \text { Shaka } & =\text { Yakushi } \\ \text { Monju } & =\text { Monju } \\ \text { Eleven-headed Kannon } & =\text { Kannon }\end{array}$

(Eleven-headed)

In order to relate the images at present in the Murō-ji kondo to the Yakushi mandala, Kobayashi had to omit from his equation the bodhisattvas Nikkō and Gakkō, who are mentioned as part of the mandala in Asabasho. Kudatsu Bosatsu is traditionally represented as a disciple of the Buddha, with hands clasped in prayer, a gesture that Kobayashi admits is lacking in the sculpture called Jizō at Murō-ji. ${ }^{8} \mathrm{He}$ identified the image in the kondo presently called Yakushi as an image of Miroku (S: Maitreya) in his

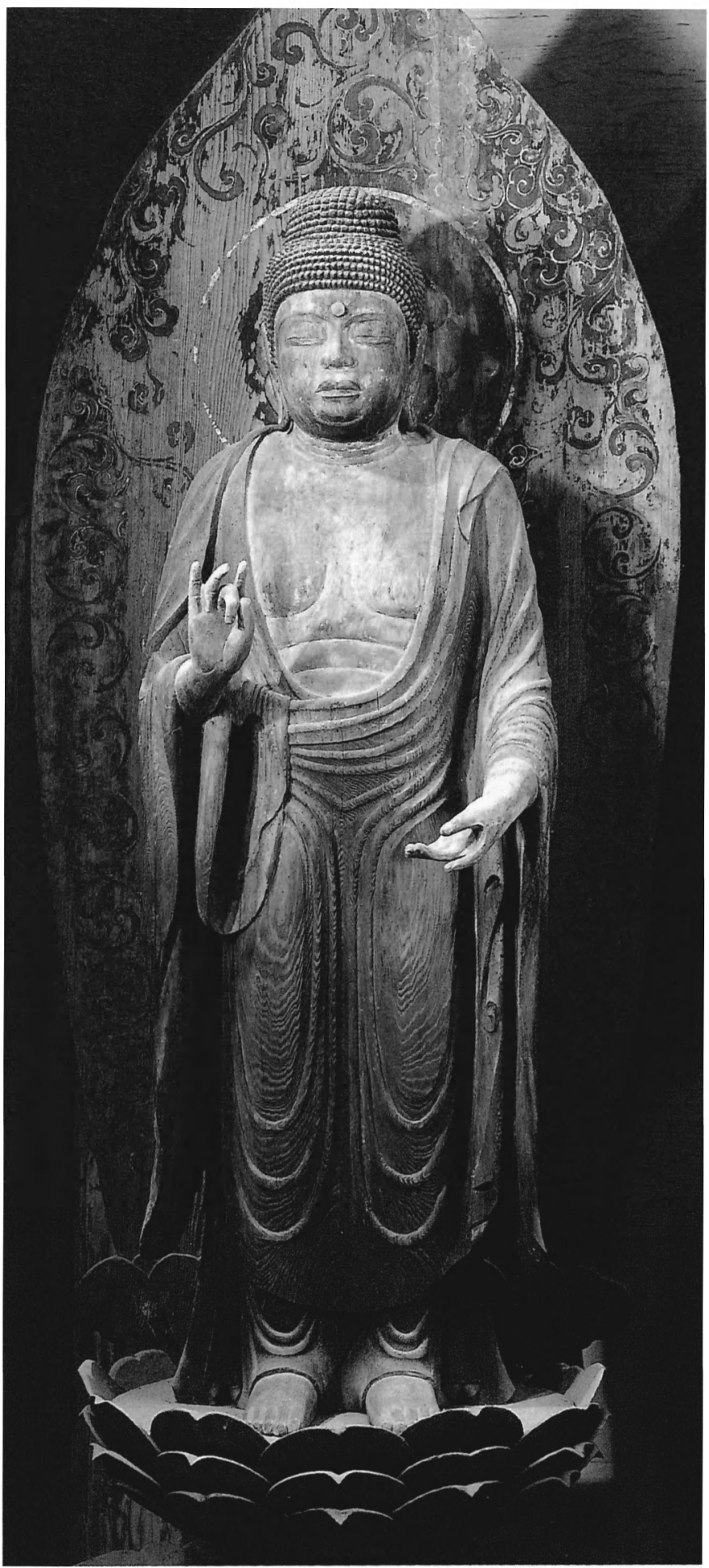

Fig. I 8. Yakushi Nyorai. Murō-ji, Nara Prefecture. $10^{\text {th }}$ c. Wood; h. I64.0 cm. Photograph courtesy of Asukaen.

form as a Buddha. At the time Kobayashi conceived his theory, the evidence found in Yamato Meishoshi to support an original triad apparently was not known; his argument 


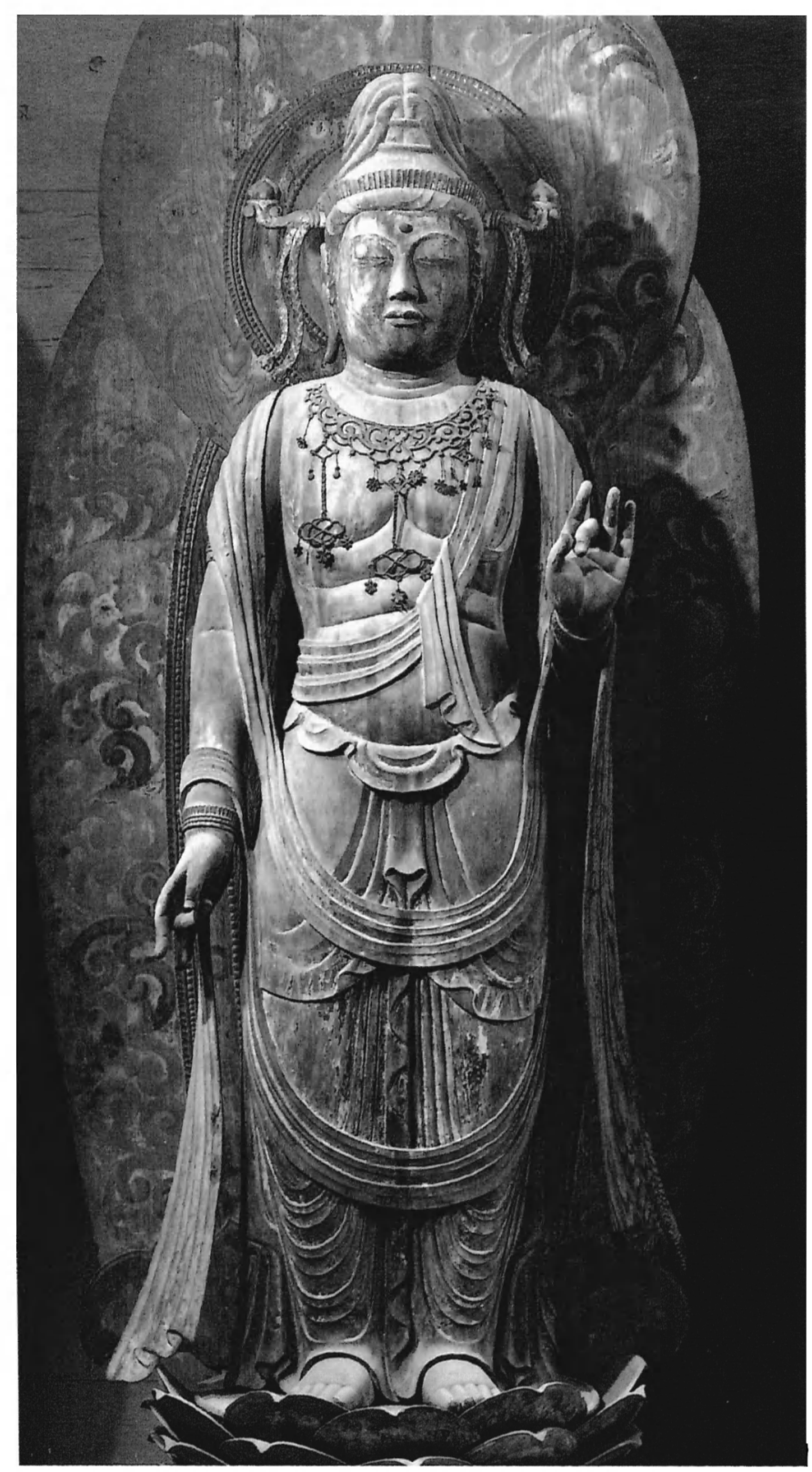

Fig. 19. Monju Bosatsu. Murō-ji, Nara Prefecture. 10 ${ }^{\text {th }}$ c. Wood; h. 205.3 $\mathrm{cm}$. Photograph courtesy of Asukaen.

assumed that the group of five was present in the hall in the ninth century. Kobayashi's equation is an intriguing one, but without other examples or evidence, it is difficult to accept. $^{84}$

In I939 Kanamori Jun had stated explicitly that identification of the Murō-ji images as Kasuga honji-suijaku was his own original hypothesis. Later secondary sources continued to repeat his argument, but absence of any apparent precedent made it easy-though incorrect-to assume that Kanamori's thesis was pure conjecture. ${ }^{85}$
Initially skeptical about the relationship of the kondō sculptures to Kasuga, I set out to uncover and evaluate evidence toward a different theory. But Jiin Meisaicho, dated Meiji 25 (I 892), demonstrates that the equation of the Murō-ji icons with the Kasuga honji-butsu was current at the time this record was written. Following a list of the five kondō sculptures, the document provides additional information about them:

During his time Kōbō Daishi himself made the Shaka and enshrined it inside [the hall]. For a period of time they called the Main Image Yakushi, which was originally with Kannon and Jizō. In looking at these images now, the central image is Shaka and to its left is Yakushi. There are reasons why it [Murō] is claimed to be the Okunoin [inner sanctuary] of Kasuga in Nara. As it exists now, the Shaka,Yakushi, Jizō, Kannon, and Monju are the honji of Kasuga. ${ }^{86}$

This passage not only states that the five images in the kondō represent the honji of Kasuga, but also that the altar originally only held three images, Yakushi, Kannon, and Jizō. Instances of noting the identity changes of images are rare. In weighing the accuracy of this information, we must balance its late date against its apparent independence of any ideological or religious agenda. Rather, the purpose of this government document was to list temple holdings. Although the document must be used cautiously, and of course its claim that Kōbō Daishi (Kūkai) sculpted the Main Image must be discounted as pious fabrication, its authors may have had access to information from the time the grouping was created. I believe the document demonstrates he persistence and pervasiveness of the idea that the Murō$i$ kondō images represent the Kasuga honji-butsu, since he statement was recorded almost two hundred years after Iurō-ji's relationship to the Kasuga/Koffuku-ji complex ad been severed.

\section{THE ADDITION OF THE YAKUSHI AND MONJU SCULPTURES TO THE GROUP}

Of the two statues that were post-ninth-century additions to the altar, one is a bodhisattva image and the other is a Buddha image. Standing to the left of the Main Image, the smaller Buddha image $(\mathrm{I} 64.0 \mathrm{~cm})$, now registered as an image of Yakushi dating from the tenth century, possesses no distinctive characteristics of Yakushi, such as a medicine jar (Fig. 18). His awkward-looking left hand may have been reworked to hold a medicine jar, and the right hand is a later repair as well. ${ }^{87}$ Standing to the right of the Main Image is a bodhisattva image $(205.3 \mathrm{~cm})$, also dating from the tenth century, now registered as Monju, although it lacks any distinctive iconographic features of Monju, such as a sword, a scroll, or a lion pedestal (Fig. 19) ${ }^{88}$ The original locations of these sculptures are unknown; probably they were brought into the hall as kyakubutsu, or "guest Buddhas"-Buddhist images that are relocated when their original homes are lost to natural or economic disasters. For a recent example, when 
Murō-ji's pagoda was severely damaged during a typhoon in September 1998, the images of the Gochi Nyorai (Five Buddhas of Wisdom) that had been enshrined inside it were moved first to the altar of the Mirokudo, across from the kondō, and then later to the hondō. ${ }^{89}$

As for the transformation of the Main Image from Yakushi to Shaka, we must ask what might have prompted it, since Yakushi is one of the five Kasuga honji-butsu. A convincing explanation is this: if the icon had maintained its original identity as Yakushi, it would have been the honji for the kami of the Second Shrine (Ninomiya); Shaka is honji of the kami of the First Shrine (Ichinomiya) in the Kasuga hierarchy, and those responsible for reorganizing the altar must have felt that the Main Image, as the largest and grandest, should be the honji of the ranking First Shrine. Thus, a less impressive and smaller image was imported to represent Yakushi. Once designated as Shaka, the ranking honji-butsu, the Main Image could be positioned in the center-the place of greatest importance-as is common in most arrangements of Buddhist sculpture. The two Shion-in sculpture arrangements, with Shaka centeredi.e., in the most prominent position-on each of the square altars, exemplify such a hierarchical layout.

The unusual constellation of five images in the Murō-ji kondō can be explained as representations of the honjibutsu of Kasuga. No other such pentad is extant, so I have enlisted a variety of types of evidence to support this theory. The same constellation at the Shion-in, a temple affiliated with Kasuga and Kōfuku-ji, was explicitly identified in written records as Kasuga honji-butsu, lending strong support to this theory. So, too, do the many references to the Kasuga honji-suijaku that occur in literature pertaining to Kōfuku-ji, which controlled Murō-ji; the lantern inscription relating Mt. Murō to the Kasuga deity; and finally statements in Jiin Meisaicho that the icons on the Murō.ji kondō altar represented the Kasuga honji-butsu.

The Yamato Meishoshi description of a triad in the Murō-ji kondō is compelling evidence that the group of five was assembled about the time its information was compiled, the late seventeenth century. Originally the hall enshrined a triad comprising Yakushi, the Healing or Medicine Buddha, flanked by Kannon and Jizō, a powerful pair especially efficacious in aiding childbirth. Health and fecundity are extremely important concerns in Buddhism, and the composition of the original triad suggests that Murō-ji was particularly committed to these matters. Since the Heian period Murō-ji has been known as a site where prayers for rain have been offered-successfully - to a dragon residing in the caves on Mt. Murō. Groups of monks gathered there for retreats to participate in sūtra reading to control the weather and promote agricultural fecundity..$^{90}$ In the later history of the temple Murōji became known as a place where women were allowed to participate in Shingon ritual (as opposed to Mt. Kōya, which was off limits to women until the nineteenth century). One manifestation of women's worship was the offering of charms to produce an ample supply of breast milk. ${ }^{9 \mathrm{I}}$ In further research I am continuing to explore the emphasis on fertility found throughout the long history of Murō-ji.

Present-day devotees at Murō-ji are apt to identify all the images in the kondō as Hotokesama, undifferentiated "Buddhas," and to address their worship without regard to the images' individual identities and canonical powers. Students of Japanese Buddhism are usually inclined to accept the identities supplied by the Agency for Cultural Affairs, ascriptions that take no account of changes over time. Both approaches have their uses, but both attenuate our understanding of this altar grouping, of the beliefs that it has represented, and of the circumstances that brought it into being. Only by delving into its historical context-both documents and images-as I have attempted to do, can we begin to understand the complex and changing significance of the Murō-ji kondō altar, and to reinvest the icons with their composite identities. 


\section{Characters}

Amenokoyane 天児屋根

Amida 阿弥陀

Amyō-in 阿名院

an-i-seppōin 安慰説法印

Anzan-ji 安生寺

Asabashö 阿婆縛抄

Asai Kazuharu 浅井和春

Asami Ryūsuke 浅見龍介

Ben'ichizanzu

Bonten 焚天

Buzan Dentsūki 豊山伝通記

Daigo-ji Yakushi 醍醐寺薬師

Daijō-in 大乗院

Daijo-in Jisha Zōjiki 大来院寺社雑事記

Dōji 童子

Döji KYō 童子経

Dunhuang 敦煌

Fangguang Pusa Ji 放光菩薩記

Fujiwara no Morosuke 藤原師輔

Fukūkensaku Kannon 不空羅索観音

Futsunushi 経津主

Gakkō 月光

Gansen-ji 岩船寺

gasshö 合掌

Gochi Nyorai 五智如来

Gokoku-ji 護国寺

Gyokuyō 玉葉

Hachiman 八幡

Han'en 範 $\mathrm{A}$

Hanzhou 漢州

Himegami 姬神

Hōgatsu Chigon Kōon

Jizaiō Butsu宝月智旅光音自在王仏

Hokkedō 法華堂

Hokke Zanmaidō 法華三味堂

Hōkō Bosatsu 放光菩薩

Hondō 本堂

honji 本地

honji-butsu 本地仏

honji-suijaku 本地垂迹

honzon 本尊

Hotokesama 仏様

Ichijō-in - 乗院

Ichinomiya - 宮

Izu 伊豆

Jiin Meisaichö寺院明細帳

Jinson 寻尊

jitahōkai 自他法界

Jizō 地藏

Jōgyōdō 常行堂

Jōruri-ji 浄瑠璃寺
Jōshū 城州

Jūichimen Kannon 十一面覾音

Jūnishinshō $十$ 二神将

Kachio-ji Amida 勝尾寺阿弥陀

Kaiyuan-si 開元寺

Kakuzenshö 鸴禅鈔

Kanamori Jun 金森遵

Kangon 觀嚴

Kanjō-in 雄頂院

Kannon 㘥・音

Kanshun 漞舜

Kasuga 春日

Kasuga Daimyōjin 春日大明神

Keishōin 桂昌院

Kengyō 賢璟

Kichiden-ji吉田寺

Kinosha 纪社

Kobayashi Taichirō 小林太一郎

Kobayashi Takeshi 小林䣓

Kōbō Daishi 弘法大師

Kōdō 講堂

Kōfuku-ji 興福寺

kondö 金堂

Konpondō Yakushi Butsu 根本堂薬師仏

Kudatsu Bosatsu 救脱菩薩

Kujō Kanezane 九条兼害

Kūkai 空海

kyakubutsu 客仏

$k y \bar{u} u$ 求雨

massha 末社

matsuji 末寺

Minami'ichi-chō 南市町

Miroku 弥勒

Mizugami 水神

Monju 文殊

Mon'yōki 門葉記

monzeki 門跡

Murō-ji 室生寺

Murōzan Sōron no Ki 室生山争論之記

Nagashima Fukutarō 永島福太郎

naijin 内陣

Nakamura 中村

Nikkō日光

Ninomiya 二宮

Ninna-ji Amida 仁和寺阿弥陀

Ōya-dera 大谷寺

raidö 礼堂

raigō 来仰

Ryūju 龍樹

Ryūketsu 龍穴

Ryūkō 隆光 
Saifuku-ji 西福寺

Sanbonmatsu 三本松

Sannomiya 三宫

Seishi 勢至.

semui'in 施無畏印

Shanji-si 善寂寺

Shaka Nyorai 䣋迦如来

shakujö 錫杖

Shichibutsu Yakushi 七仏薬師

shinbutsu-bunri 神仏分類

shinbutsu-shūgö 神仏習合

Shindō 新堂 (or 真堂)

Shingi Shingon-shū Buzan-ha 新義真言宗豊山派

Shinomiya 四宮

Shion-in 四恩院

Shō Kannon 聖観音

Shōchō 承澄

Shōfuku-ji 正福寺

Shōrin-ji 聖輪寺

Shōtoku Taishi 聖德太子

suijaku 垂迹

Tachibana Anjō 橘安縄

Taishakuten 帝釈天

Takemikazuchi 建鉂雷

Tamai Sadatoki 玉井定時

Tōdai-ji 東大寺

Tōdai-ji Yōroku 束大寺要録

Tōnoo 当尾

\section{Notes}

* I should like to acknowledge the generous support of the Social Science Research Council, Japan Society for the Promotion of Science Postdoctoral Fellowship, and the Metropolitan Center for Far Eastern Art Studies.

I. Domon Ken et al., Murd-ji, vol. I of Nihon Mei Kenchiku Shashin Senshu (Tokyo: Shinchōsha, I992), p. I I 4 ; Ōta Hirotarō et al., Muro-ji, vol. 6 of Yamato Koji Taikan (Tokyo: Iwanami Shoten, I976), p. I7; Naraken Kyōiku Iinkai, Kokuho Muró-ji Kondo Shüri Koji Hokokusho (Nara: Nara-ken Kyōiku Iinkai, I99I), p. 4.

2 . There is evidence that this seventeenth-century raid $\bar{o}$ replaced one built earlier, during the Kamakura period (I $185-1333$ ). See Sherry Fowler, "Murō-ji: A Contextual Analysis of the Temple and Its Images" (Ph.D. diss., University of California, Los Angeles, I995), p. 6I .

3. Washizuka Hiromitsu, Muro-ji, vol. I 3 of Nihon no Koji Bijutsu (Osaka: Hoikusha, I99I), p. 44.

4. See Fowler, "Muro-ji,"pp. I24-30, for a discussion of the Main Image as a Yakushi.

5. Asabashō, in Dai Nihon Bukkyō Zensho (Tokyo: Bussho Kankōkai, I9I7), vol. 36, p. 317 .
Tōshōdai-ji kondō唐招提寺金堂

Tsuji Hidenori 逵日出典

Tsuruga 敦賀

Uda 宇陀

Wakakusa 若草

Wakamiya 若宫

Yabu no naka sanzon 数の中三尊

yakko 薬壼

Yakushi 薬師

Yakushi Rurikö Shichibutsu Hongan

$K u$ doku Kyö薬師瑠璃光七仏本願功德経

Yakushi Rurikōö Shichibutsu Hongan Kudoku Kyö Nenjugiki

薬師瑠璃光王七仏本願功德経念誦義軌

Yakushidō薬師堂

Yakushi-ji 薬師寺

Yamabe 山辺

Yamashiro 山城

Yamamoto Tsutomu 山本勉

Yamato Meishōshi 大和名勝志

Yijing 義淨

yogan'in 与願印

Yokokawa 横川

Yoshihide 良秀

yükyaku 遊脚

Zen'en 善円

Zennyō Ryūō 善如龍王

Zhang Sengyou 張僧跞

Zuishin-in 随心院
6. In the record Denpo-kanjo Saho, "Yakushidō" is written next to a drawing of this building. The original drawing was dated Kengen 2 (1 303), but the record survives in a copy dated Bun'an I4 (I445). See Tanaka Minoru, "Ichiji Kechien Hokekyo; Denpō-kanjo Sahö ni tsuite," Nara Kokuritsu Bunkazai Kenkyüjo Nenpö (1963), pp. 36-37. In addition, Ben'ichizanzu, a map of the Murō-ji precinct dated Shōwa 3 (I 3 I 4), has "Konpondō Yakushi Butsu" ("Principal hall, Yakushi Buddha") written next to a drawing of the kondō. See Kanagawa Kenritsu Kanazawa Bunko, Kanazawa Bunko Shiryö Zensho (Kyoto: Benridō, 1988), vol. 9, fig. I77, p. 345; Ōta, Muro-ji, p. I 8, n. 2 and pp. 68-70.

7. Maruo Shōzaburō, "Yoshino, Uda, Asuka Junrei," Gasetsu (January I94I), p. 49; Kameda Tsutomu, "Sanbonmatsu no Jizō Son," Bijutsu Kogei, vol. I I (February I943), p. 86. See also Murō Sonshi Henshū Iinkai, Murō Sonshi (Nara: Murō Murayakuba, 1976), pp. 791-93, 6 I 8, 430. The image is now enshrined in the main building of Anzan-ji, a new concrete storehouse on a plain to the north of Sanbonmatsu train station. Previously it had belonged to a temple located near this site called Shōfuku-ji, also known as the Shindō.

8. Ōta, Muro-ji, p. 39.

9. Tokyo National Museum, Yamato Koji no Hotoketachi, exhib. cat. (Tokyo: NHK, I993), p. 207.

I0.The Sanbonmatsu Jizō and the Murō-ji Jizō mandorla were reunited for the first time in the exhibition held at the Nara National Museum 
in I 987. Nara National Museum, Bosatsu, exhib. cat. (Nara: Nara National Museum, 1987), figs. 82-83, pp. 93-95, 206.

I I. Shimizu Zenzō, personal communication, 30 September, I99 I.

I 2. Yamato Meishoshi (ca. I70I), (Nara: n.p., n.d.), Murō-ji section, unpaged.

I3. Circa I7OI is the date I have tentatively assigned to Yamato Meishoshi.The actual document belongs to the Tamai family, descendants of the principal author, Tamai Sadatoki (1646-I720), a government official of Nara. There is some information about the document in Nara Kenritsu Nara Toshokan, Kyodo Shiryo Mokuroku (Nara: Nara Kenritsu Nara Toshokan, I979), pp. 28I-82. The document has not been republished, and it is only available in microfilm at the Nara Prefectural Library. Mizuno Keizaburō was the first to use this document in connection with the Murō-ji sculptures, and he dates its compilation between the Genroku and Hōei eras (I688-I7II). See Mizuno Keizaburō and Tsujimoto Yonesaburō, Murס-ji, vol. 6 of Yamato no Koji (Tokyo: Iwanami Shoten, I98I), p. 2. The last date in the Murō-ji section is Genroku I4 (I70I) and a note in the margin of this section is dated Genroku is (1702), indicating that the note was added after the main text was written. On these bases I date the compilation of the text to ca. I70I.

I 4. A list of Murō-ji's treasures, Murס-ji Meisaich $\overline{\text {, }}$ published in Kan'en 3 ( 1750 ) by Gokoku-ji in Edo, lists the Main Image of the kondō as Yakushi, and a list owned by Murō-ji called Yamatokuni Uda-gun Murסzan Meisaich $\delta$, from Meiji I 3 (I 880), also records the figure as Yakushi. Cited in Tanaka Sumie et al., Murס-ji; Koji Junrei, Nara (Kyoto:Tankōsha, 1979), p. I07. Moreover, in Kawai Keiichi, Wash Keiichi, I 895), sect. 8, p. I 3, the kondō images are listed as Yakushi, Kannon, Nikkō, Gakkō, and the Twelve Guardian Generals. Some of the author's identifications may be mistaken, but it is still significant that he listed Yakushi first.

I s. Nara-ken, Jiin Meisaichø: Uda-gun (Nara: Nara-ken, I 892), Murōji section, unpaged. The record goes on to explain that the five present images are the honji of Kasuga, a topic which will be addressed later in this article.

I 6. Ōta, Murס-ji, p. 40.

I7. For a photo reconstruction of the triad, see Nishimura Kōchō et al., Jitichimen Kannon: Nara, Murס-ji, vol. 2 I of Miwaku no Butsuzб (Tokyo: Mainichi Shinbunsha, I992), p. 50.

I 8. Asai Kazuharu, "Heian Zenki Jizō Bosatsuzō no Kenkyū," Tokyo Kokuritsu Hakubutsukan Kiyб, vol. 22-I (1986), pp. 5-125.

19. Kakuzensho, in Dai Nihon Bukkyб Zensho (Tokyo: Bussho Kankōkai, I9I7), vol. 46, p. 366. The mandala description is in the uragaki (postscript) of the Doji Kyo. Shichibutsu Yakushi is explained in the Yakushi Rurikoo Shichibutsu Hongan Kudoku Kyo Nenjugiki. For more

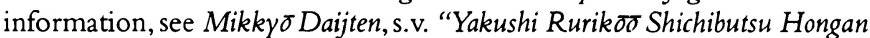
Kudoku Kүo Nenjugiki."

20. Asai,"Heian," p. 55; Kobayashi Taichirō,"Dõji Kyōhō Oyobi Dõji Kyō Mandara," Mikkyб Kenkyü, vol. 84 (I943), pp. 40-4I. The second form of Yakushi is Hōgatsu Chigon Kōon Jizaiō Butsu, according to the sūtra Yakushi Ruriko Shichibutsu Hongan Kudoku Kyo (S: Bhagavannbhaisajyaguru-vaidurrya-prabhasa-purva-pranidhana-visesa-vistara-namamahayana Sutra, translated into Chinese by Yijing (635-713).

21. Asabasho, in Dai Nihon Bukkyб Zensho (Tokyo: Bussho Kankōkai, I9I7), vol. 38 , p. 332 .

22. Kobayashi Taichirō, "Dōji," pp. 42-44; Kobayashi Taichirō,"Tōdai no Guku Kannon," in Bukkyб Geijutsu no Kenky d. (Kyoto: Tankōsha, 1974), p. 203. See also Françoise Wang-Toutain, Le bodhisattva Ksitigarbha en Chine du Ve au XIIIe siècle (Paris: Ecole française d'Extrême-Orient, I998), pp. 296-97.

23. Kobayashi Taichirō, "Dōji," p. 42; Matsushima Ken, "Jizō Bosatsu Zō," Nihon no Bijutsu, vol. 239 (April I986), p. 28. See also Kakuzensho, in Dai Nihon Bukkyo Zensho (Tokyo: Bussho Kankōkai, I917), vol. 47, p. 7 .

24. Asai,"Heian," p. 23, fig. 3

25. Asai, "Heian," pp. 23-26.
26. No illustration of Cave 176 is included in Asai's study, and I have not yet been able to locate one. Cave 205 is illustrated in Asai, "Heian," p. 25, fig. 4; and in Zhongguo Bihua Quanji: Dunhuang 6 Shengtang (Tianjin: Tianjin Renmin Meishu Chubanshe, I989), vol. 6, p. 50, pl. 5I; and in Roderick Whitfield and Anne Farrer, Caves of the Thousand Buddhas

(London: British Museum Publications, I990), p. I 8.

27. Asai, "Heian," p. 25.

28. Takakusu Junjirō and Watanabe Kaigyoku, eds., Taishō Shinsh $\bar{u}$ Daiz ðky (Tokyo: Taishō Issaikyō Kankōkai, I 925), vol. I4, no. 450, p. 407a. See also M.W. de Visser, Ancient Buddhism in Japan; Satras and Ceremonies in Use in the Seventh and Eighth Centuries A.D. and Their History in Later Times (Leiden: Brill, 1935), vol. II, p. 537; Barbara Ambros, "Pilgrimages of Noblewomen in Mid-Heian Japan," Japanese Journal of Religious Studies, vol. 24, no. 2/3 (Fall I 997), p. 336.

29. Chrgoku Sekkutsu: Tonko Bakko Kutsu (Tokyo: Heibonsha, 1987), vol. 3, fig. I25. For a written description, see Duan Wenjie, Dunhuang Art:Through the Eyes of Duan Wenjie, ed. Dan Zhong (New Delhi: Indira Gandhi National Centre for Arts, Abhinav Publications, I994), p. 302.

30. Duan, Dunhuang, p. 334 , gives a written description. A photo of the image can be found in Zhongguo Bihua Quanji, vol. 6, p. I66, pl. I6I.

3 I. Henrik Sorenson, "The Buddhist Sculptures at Feixian Pavilion in Pujiang, Sichuan," Artibus Asiae, vol. LVIII, no. I/2 (1998), fig. I9, p. 59.

32. Henrik Sorenson, "Sculpture at the Thousand Buddhas Cliff in Jiajiang, Sichuan Province," Oriental Art, vol. XLIII, no. I (Spring 1997), fig. I9, p. 46.

33. Zhiru, "Dizang (Kșitigarbha) Belief and Pure Land Development: A Missing Piece in the History of Medieval Chinese Buddhism," paper presented at the Twelfth International Association of Buddhist Studies Conference, held in Lausanne, Switzerland (August I999), pp. I I-I 3. Zhiru advises that the identifications made by the Sichuan Academy should be used with caution, pending the discovery of more conclusive evidence.

34. Ho-am Art Museum, Koryŏ, Yöngwönhan Mi: Koryö Purhwa T'ukpyöljön, exhib. cat. (Seoul: Samsung Misul Munhwa Chaedan, I993), cat. 20, p. 73. See also Kikutake Jun'ichi, Koryö Sidae ui Purhwa, exhib. cat. (Seoul: Sigongsa, I 997), cat. 1 20, p. 1 07. The painting, on silk, measures $99 \times 52.2 \mathrm{~cm}$. Another painting of Kannon and Jizō from the Koryŏ dynasty is owned by Amyō-in, Gifu Prefecture. See Kikutake, Koryŏ, fig. I 26; and Takeda Kazuaki, "Gifu Amyō-in no Kannon, Jizō Bosatsu Heidachi Zu ni tsuite," Museum, vol. 477 (December I990), pp. $2 \mathrm{I}-34$.

35. Ho-am, cat. I I, p. 43-47. See also Junghee Lee, "Ho-am Art Museum: Major Private Collection," Korean Culture, vol. 8, no. I (1987), p. 37. The painting is on silk and measures $110 \times 51 \mathrm{~cm}$.

36. Kangon (I I I-I 236), comp., Todai-ji Yoroku, ed. Tsutsui Eishun (Osaka: Zenkoku Shobō, 1 944), p. 373. The donor later had the two images moved to the $k \delta d \delta$ at Tōdai-ji.

37. Asai, "Heian," p. 55. Asai quotes Mon'yoki for Tenryaku 8 (954), tenth month, but as this long record is in 89 nonchronological sections, I have not yet located this reference. The editor and compiler of Mon'yoki was Son'en Shinnō (1 298-1 356). See Takakusu and Watanabe, eds., Taish $\delta$, $\mathrm{Zuz \sigma}$ Hen, vols. I I and I 2 , nos. I-I 84.

38. Nāgārjuna $\left(2^{\text {nd }} / 3^{\text {rd }}\right.$ c. CE) was a famous exponent of Mahāyāna Buddhism.

39. Asai, "Heian," p. 55; Todai-ji Yoroku, p. 308.

40. Matsushima," "Jizō," p. 3 I , fig. 46. See also Kuno Takeshi, Sekibutsu, vol. 36 of Book of Books, Nihon no Bijutsu (Tokyo: Shōgakkan, I 975), pp. I 66-70, pls. $4 \mathrm{I}-43$, figs. $85-87$.

$4 \mathrm{I}$. Tōnoo, northeast of Nara city, was considered part of Yamato in premodern times.

42. Kinki Bunkakai, Kasagi, Kamo, vol. Is of Kinki Nihon Books (Kyoto: Sōgeisha, 1990), pp. 8I-82, fig. 25.

43. Kinki, Kasagi, Kamo, p. 82. Many stone images in the area were carved by members of the Tachibana family. There are several examples 
of asymmetrical stone triad arrangements in Korea, such as the Sŏsan triad dating from the seventh century. See Jonathan W. Best, “The Sǒsan Triad:An Early Korean Buddhist Relief Sculpture from Paekche," Archives of Asian Art, vol. 33 (I980), pp. 89-108.

44. Fowler, "Murōjii," pp. 2 I 4-20.

45. Asami Ryūsuke, "Izu, Kyū Kichiden-ji no Amida Sanzon Zō, Bishamonten Zō ni tsuite-Kannon to Jizō o Kyōji to Suru Issaku Rei," Museum, vol. 552 (February I998), pp. 7-3I. The triad is now in the Tokyo National Museum.

46. Asami, "Izu," p. 26, proposes that these two images, a twelfth-century image of Amida from a private collection and a Jizo from the Nezu Art Museum, once belonged to the same triad, along with a Kannon image now missing. The Amida and Jizō images have similar inscriptions, naming the same patron and date, Kyūan 3 (I I 47), and contained the prayers for rain. For the full inscriptions, see Asami, "Izu," p. 30, n. 46.

47. Allan Grapard, "Honjisuijaku," in The Encyclopedia of Religion (New York: Macmillan, 1987). See also Stanley Weinstein, "Honji suijaku," in Kodansha Encyclopedia of Japan (Tokyo and New York: Kodansha, I983). 48. Tsuji Hidenori, Shinbutsu Sh $\bar{g} \delta$ (Tokyo: Rokkō Shuppan, I986), pp. 99-102.

49. James Edward Ketelaar, Of Heretics and Martyrs in Meiji Japan; Buddhism and Its Persecution (Princeton: Princeton Univ. Pr., I990), pp. 65-66.

50. Susan Tyler, "Honji Suijaku Faith," Japanese Journal of Religious Studies, vol. I6, no. 2/3 (1989), p. 227.

51. Allan Grapard, "Japan's Ignored Cultural Revolution: The Separation of Shinto and Buddhist Divinities in Meiji (Shimbutsu bunri) and a Case Study: Tōnomine," History of Religions, vol. 23, no. 3 (I984), pp. 240-65; Susan Tyler, The Cult of Kasuga Seen Through Its Art (Ann Arbor: Center for Japanese Studies, I992).

52. Ian Reader and George J. Tanabe, Jr., Practically Religious: Worldly Benefits and the Common Religion of Japan (Honolulu: Univ. of Hawai'i Pr., I998), pp. I48-5 I.

53. Allan Grapard, Protocol of the Gods: A Study of the Kasuga Cult in Japanese History (Berkeley and Los Angeles: Univ. of California Pr., 1992), pp. 82-90, 93. See also Tyler, Cult, p. 92, for other variations of Kasuga honji-suijaku.

54. See Sekiguchi Masayuki, "Suijakuga," Nihon no Bijutsu, vol. 274 (1989), fig. 9. See also Tyler, Cult, pl. I 2.

55. Nara National Museum, Kasuga Shinkō no Bijutsu, exhib. cat. (Nara National Museum, I997), cat. I 5, pp. 20-2 I. See also Bunkachō Bunkazai Hogobu, "Shinshitei no Bunkazai," Gekkan Bunkazai, vol. 4I 7 (June I998), pp. IO-I I.

56. Yoko Woodson, Exquisite Pursuits: Japanese Art in the Harry G.C. Packard Collection, exhib. cat. (San Francisco: Asian Art Museum of San Francisco, 1994), fig. I 2, pp. 60-63.

57.Jinson (1430-I 508), et al., Daijo-in Jisha Zojjiki, ed.Tsuji Zennosuke (Tokyo: Sankyō Shoin, I93 I), vol. 3, pp. 37-39. For information about Jinson and the Daijo-in Jisha Zöjiki, see Grapard, Protocol, pp. I 7 I-85.

58. Kageyama Kōshirō, "Kasuga Honji-butsu no Zōzō ni tsuite," Shiseki to Bijutsu, vol. I95 (1949), p. I 34 . See also Tsuji Hidenori, Shinbutsu, pp. IO3-4.

59. Tyler, Cult, pp. I77, I 80. See also Jinson, Daijo-in, vol. 7, p. 252 (entry for Bunmei I 3 , first month, fourth day).

6o. Jinson, Daijo-in, vol. 3, p. 39

6I. Kageyama, "Kasuga," p. I 35; Tsuji Hidenori, Shinbutsu, p. I04.

62. In addition, an entry from Daijo-in Jisha Zöjiki, Chōroku 3 (I 458 ), second month, seventh day, mentions that four of these five deities (excluding Shaka) representing the Kasuga honji-butsu were enshrined in the Jibutsudō at Daijō-in. See Jinson, Daijo-in, vol. 2, pp. 72-73; Kageyama, "Kasuga," p. I 35 . Suzuki Ryōichi, Daijo-in Jisha Zöjiki (Tokyo: Soshiete, I983), p. I 2 I, postulates that a Shaka image, also mentioned in the entry above, was brought from the Zuishin-in in Kyoto to complete the group of five.
63. Yamamoto Tsutomu, "Tokyo Kokuritsu Hakubutsukan Hokan: Monju Bosatsu Ryūzō," Kokka, vol. I2 Io (1996), pp. I6-22.

64. Yamamoto, “Tokyo," p. 21. See also Metropolitan Museum of Art, The Arts of Japan: An International Symposium (New York: Metropolitan Art Museum, 2000), p. 29.

65. Kuno Takeshi, "Daibusshi Zen'en to Sono Sakuhin," Bijutsu Kenkyu, vol. 240 (May I 965), pp. I-17. See also Michael Cunningham, Buddhist Treasures from Nara, exhib. cat. (Cleveland: Cleveland Museum of Art, I998), pp. I02-3, and Nara National Museum, Kasuga, cat. 25, p. 30, regarding the Eleven-headed Kannon image.

66.Yamamoto also noted (p. 22, n. I I) the existence of two other wooden images, now owned by Tokyo Geijutsu Daigaku. These two similar sculptures of Monju and Jizō both bear inscriptions on their bases stating that they were made in Chōroku 4 ( 1460 ) as honji-butsu of a shrine in Yamabe, Uda district. See Tokyo Geijutsu Daigaku, Tokyo Geijutsu Daigaku Geijutsu Shiryokan: Zöhin Mokuroku, Chokoku I (Tokyo: Tokyo Geijutsu Daigaku, I $98 \mathrm{I}), \mathrm{p}$. I4, figs. 54, 55. It is very likely that these two were originally part of a group of five Kasuga honji-butsu. Furthermore,Yamabe is not far from Murō-ji, which indicates that the cult was present in the Murō-ji area.

67.Tsuji Hidenori, Shinbutsu, p. I00;Tyler, Cult, p. 92; Grapard, Protocol, p. 80.

68. Kujō Kanezane (I I 49-I 207), Gyokuyō (Tokyo: Takatō Chūzō, I9I7), vol. 2, p. 282.

69. Suzuki, Daijo-in, pp. 6I-62; Jinson, Daijo-in, vol. I, p. 245, entry for Kōshō 3 (1457), ninth month, eleventh day.

70. Nara National Museum, Nyonin Kōya: Muro-ji no Mihotoketachi, exhib. cat. (Tokyo: Yomiuri Shinbun, 1999), fig. I 8, pp. 62, 99; Nara National Museum, Muro-ji no Bijutsu, exhib. cat. (Nara: Nara National Museum, I974), fig. 38, pp. I4, 23.

71. Nagashima Fukutarō, Nara Bunka no Denryü (Tokyo: Chūokōronsha, I944), p. 438. See also Royall Tyler, "Kofukuji and the Mountains of Yamato," Japan Review, vol. I (1990), p. I68.

72. Nara-ken Uda-gun Yakusho, Nara-ken Uda-gun Shiry $\sigma$ (Nara: Naraken Uda-gun Yakusho, I9I7), p. I06.

73. Nara-ken Uda-gun Yakusho, Nara-ken, p. I07.

74. Kasuga no Kamigami Hensan Iinkai, Kasuga no Kamigami (Nara: Kasuga Rengōkai, I99I), p. 427, lists four Kasuga shrines in Murō village at present.

75. Murō Sonshi, Murō, p. 757

76. Buzan Dentsaki, in Dai Nihon Bukkyō Zensho, vol. Io6 (Tokyo: Bussho Kankōkai, I9I7), p. 77.

77. Tsuji Hidenori, Muro-jishi no Kenkȳ (Tokyo: Gannandō Shoten, 1979), pp. I89-90. See Murбzan Sōron no Ki (Nara: Nara Bukkyō Shinbunsha, 1926). The record was not published until 1926 , but it is reprinted from the contemporary records of the appeals.

78. See Grapard, Protocol, pp. 88-90. The five kami acquired their group identity after the Wakamiya was built in I 135 .

79. Yamato Meishoshi, Murō-ji section, unpaged.

8o. Ōta, Muro-ji, p. I I.

8I. Kanamori,"Murō-ji Kondō Gozō Kō," Kokka, vol. 587 (I939), p. 320. See also Washizuka, Murōji, p. 87.

82. Kobayashi Takeshi, "Murō-ji no Kondō Gobutsu ni tsuite," in Nara Kokuritsu Bunkazai Kenkyujojo Gakuhō(Nara:Yoshikawa Kōbunkan, 1959), vol. 8, pp. $2 \mathrm{I}-27$.

83. Takakusu and Watanabe, Taish $\delta$, vol. I 4 , no. 450, p. 407b. The Yakushi Sūtra states that Kudatsu makes this mudrā. See also de Visser, Ancient Buddhism in Japan, vol. II, p. 537.

84. According to Tsuji Hidenori, Muro-jishi, p. I I 8, Kobayashi later retracted his theory, but Tsuji does not give a reference.

85. Kanamori, "Murō-ji,"Kokka, vol. 584 (1939), pp. 208-9 and Kokka, vol. 587 (1939), p. 320.

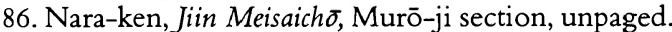

87. Ōta, Muro-ji, pp. 43-44.

88. The Monju image has the mudrā of an-i-seppoin (S: vitarkamudrā), which symbolizes appeasement and preaching. Although uncommon, 
this mudrā may be seen in Japanese images of Monju Bosatsu. See E. Dale Saunders, Mudrã (Princeton: Princeton Univ. Pr., I960), p. 75. See also Ōta, Muro-ji, pp. 41-43, for more on this sculpture.

89. Nara-ken Kyōiku linkai, Kokuho Murōji Gojntö Shøri Köji Hokokusho (Nara: Nara-ken Kyōiku Iinkai, I979), figs. 69-70. See also Tanaka Sumie, Muro-ji, p. I 20, for a picture of the images inside the pagoda. For a photograph of the destruction of the pagoda, see Nara National Museum, Nyonin Koya, p. 4. The Gochi Nyorai were returned to the pagoda after its reconstruction was completed in $200 \mathrm{I}$.
90. Sherry Fowler, "In Search of the Dragon: Mt. Murō's Sacred Topography," Japanese Journal of Religious Studies, vol. 24, no. I/2 (Spring I997), pp. I 46-6I.

91. Sherry Fowler, "Setting Foot on the Mountain: Mt. Murō as a Women's Alternative to Mt. Kōya:" Asian Journal of Women's Studies, vol. 3 , no. 4 (1998), pp. 66-67 